Article

\title{
Communicating Sustainability: Using Community Media to Influence Rural People's Intention to Adopt Sustainable Behaviour
}

\author{
Md. Shahzalal ${ }^{1, *}$ and Azizul Hassan ${ }^{2}$ \\ 1 Department of Marketing, Begum Rokeya University, Rangpur, Rangpur 5400, Bangladesh \\ 2 Tourism Consultants Network, the Tourism Society, London SE1 0AA, UK; azizulhassancmet@gmail.com \\ * Correspondence: shahzalalstar@gmail.com
}

Received: 10 November 2018; Accepted: 31 January 2019; Published: 4 February 2019

check for updates

\begin{abstract}
Sustainable development is a big challenge for developing countries, due to lack of effective communication about sustainability to the rural population. This paper aims at building a theoretically and statistically sound model to communicate sustainability more effectively in rural areas in order to achieve sustainable development. To this end, the constructs and items of the hypothesised model are identified, based on a focus group discussion and backed by the literature reviewed. Both partial least squares and covariance-based structural equation modelling approaches were used to test the hypotheses and validate the model against multiple indices after analysing survey data collected from 300 community radio listeners in Bangladesh. It was found that the unique media characteristics of community radio positively increased the acceptability of sustainability communications, which in turn affects the behavioural determinants (popular theory: attitudes, self-efficacy belief and social norms) and changed the intention to adopt sustainable behaviour. Example cases from around the world also support the statistically sound model. The paper also provides implications and directions for future research.
\end{abstract}

Keywords: sustainability communications; sustainable development; community radio; behavioural determinants; intention and behaviour; structural equation modelling (SEM); developing country

\section{Introduction}

Although sustainable development is a pervasive need, rural people in many developing countries are still far from achieving it $[1,2]$. This is mainly due to the vast scope of sustainable development [3,4] and the absence of interventions in support of sustainability in rural areas by communication through effective media $[5,6]$. Therefore, many development researchers have found that only highly accepted media and effective communications can change the attitudes and behaviour of rural people [5-11] towards bringing a lasting and meaningful change in society [5-14]. Effective communications for sustainable development may refer to the communications that incorporate education, conversations, dialogues or active participation of both beneficiaries and benefactors $[15,16]$ to improve people's knowledge, level of self-confidence and sensitivity to others' choices of sustainable actions $[5,7,13]$. Alongside this, effective media may denote media that people simultaneously can access for information, education and exchange of views and news, and in which they can participate as planners, producers and performers [17-19].

Community radio (CR) is an effective medium for communication [17,19-21]. It is a small-sized radio station owned and managed by a community or its representative to be heard and informed and become more decisive agent regarding any contextual issues for its own sake [7]. It is a medium that is "pervasive, local, extensive, flexible, available, readily understood, personal, portable, speedy, 
and efficient" [21] (p. 1), and therefore, has established a new relationship between a medium and its listeners [22,23]. The first two CRs in its history were introduced with the motto of removing poverty and social injustice in Latin America in 1947 [24]. The primary role of this non-profit social institute is to democratise communication through community participation to solve specific needs in various social contexts and implement the development agenda [20,25]. Therefore, throughout the developing world since the 1990s, community radios have been established faster than either state or commercial radios; across Africa, they multiplied by 1,386 percent between 2000 and 2006, as well as growing remarkably in Asia [26,27] and Latin America [28]. After great success in Thailand, Indonesia, Philippines, Nepal and India [29], it is a reasonable assumption that radios can play a critical role in harnessing information communication technologies (ICTs) for development in Bangladesh [26], where currently $17 \mathrm{CRs}$ are in operation [30]. In this country, as the socio-economic developmental gap between rural and urban areas is significant [31], only mass popular access to ICTs can improve the situation [30]. Therefore, CRs were launched in Bangladesh in 2011 with the motto of institutionalising citizen's participation in local government, building capacity to adapt with climate change effects, achieving socioeconomic and environmental sustainability and protecting local culture, identity and language [32-35].

Community radio has proved to be a sustainable media for poor and marginalised populations [7]. This community broadcasting service is the third pillar of media, alongside commercial and public broadcasters $[35,36]$. Although community radios share a few characteristics with other social media (e.g., user-generated content), both theoretically and practically, community radio is unique when compared to its commercial and public service counterparts [25]. Its purpose and pattern of communication are different from the conventional social media. For example, it is a real participatory broadcaster (face-to-face meetings between the beneficiaries and the benefactors happen frequently and easily), a grassroots media, voice of the voiceless and a tool for progressive social change and development to protect local culture and language [24,25,30,32-37].

Moreover, community radio is independent of both government and private individuals and is governed by the community it serves, therefore, it has become a vital part of a healthy, pluralistic media sector [35]. Unlike other social media, a community radio mainly targets rural, disadvantaged, vulnerable and hard to reach populations instead of mainstream population [30]. Researchers claim that "the globalized commercial media can never respond to the socio-economic and development needs of the countries they reach, let alone those of marginalized communities within those countries with irrelevant entertainment, whereas CRs deal with local issues in the local languages and cultural context, relating to local problems and concerns, and aiming to help the community develop socially, culturally and economically" [24] (p. 70).

Community radio is a media platform for the excluded, including the Dalits (i.e., mostly live in semi-urban and municipal areas; work as sweepers and cleaners or employed in other most menial or low paid risky jobs; have no legal access to health, education, housing and enjoyment), Santal (i.e., one of the tribal community who are mostly seasonally employed by landlords in the rural agriculture sector with low wage), street children (i.e., with no parental identity), physically challenged people and other marginalised people for expression, learning, cultural sharing, and so on [32]. Therefore, a $\mathrm{CR}$ is being perceived as a pioneer media to localise sustainable development goals for everyone [34].

Principally, a community radio absorbs the communicative sustainability (CS) phenomenon, which includes communicative factors coming into play in making a message sustainable [38]. Communicative sustainability explains that the design and process of a development communication should be such that it promotes communicative resources (e.g., technological, educational, etc.), reduces communicative dependency (e.g., for understanding, probing, clarifying and relating an issue to one's community, etc.) and removes the impacts of disturbance (e.g., minority/majority's language, variation in gestures and uneven social power relations, etc.) in defining and implementing development goals and their adoption by all the beneficiaries [39]. Communicative sustainability focuses on localism as well as enthusiastically involving people in sharing decision outcomes with each other in their 
community [40]. It allows arguing on a decision as well as enables the target population to understand the original aim and purpose of the communication while creating time, place and context-based utility of knowledge regarding sustainability [38].

Although community radio is not the only social media in Bangladesh, it is a powerful platform for communication [36]. It has importance to rural areas and marginalised communities not only from the perspective of the government's "Access to Information (a2i) Program" [30] (p. 100) but also from many other aspects. For example, countryside people do not have access to commercial FM radios that cover only the metropolitan areas. Also, most rural people do not have access to conventional social media as they cannot use the internet (most of them do not have a computer, email account or even a smartphone, and many of them lack a formal education), although this is not very unusual compared to many other developing countries. Moreover, government administrations control the government/national radios. The programs aired by those radios are not capable to meet the needs of a specific community. Furthermore, considering the socioeconomic status of Bangladesh, CR is the cheapest ICT platform in terms of investment, sustainability and accessibility to a large illiterate population for health, sanitation and environmental improvement [30]. Also, it has become a driver of sectoral-based development (e.g., for agriculture: farm radio-locally known as Krishi radio), as well as a key player in rebuilding the socio-economic condition of vulnerable communities in the coastal areas during post-disaster periods by airing multiple motivational development programs [33,37].

It is claimed that effective communications through effective media might be a key to sustainable development of marginalised or poor communities in developing countries [16], but there is still a paucity of research in the use of effective media in sustainability communication. For instance, current research in sustainability communication is mostly exploring persuasive communication and behavioural determinants [41,42], communication for social change [41], communication for normative aspects of sustainability and various social subsystems as communicators [16], as well as environmental campaigns to advancing public dialogue [43].

On the other hand, although community radio might have an extensive role in sustainability communication, so far, research has mostly been carried out only on its supply side, for example, the roles of CRs in disaster risk reduction [44]; engagement of community members in management, ownership and communication of CRs [45-47]; assessment of the levels of women's participation in community radio stations [48,49]; attitude to CRs [50]; funding and sustainability of CRs [33]; program module development for women's empowerment [51,52]; understanding listeners (number and types of listeners, choice of programs, and where and how much people listen to CRs) [53]; etc. However, no quantitative or model-based study has been conducted yet to understand how communications about sustainability by CRs can be used to target poor communities and how that can affect people's behavioural intention towards sustainable development. Therefore, the aim of this study is to contribute to this identified knowledge gap by developing a structural model that shows the impact of community radio on the rural people's intention to engage in sustainable practices.

The research framework is based on the following questions: Do the unique media characteristics of CRs influence listeners to quickly accept sustainability communications aired by the CRs? Does quicker acceptance of sustainability communications by the listeners positively affect their behavioural determinants? Do changes in the behavioural determinants positively affect the listeners' intentions to adopt sustainable behaviour? This study aims to explore the unique media characteristics of CRs in terms of sustainability communications; various sustainability communications aired by the community radios in Bangladesh; how the unique characteristics of CRs influence rural people to accept the sustainability messages aired by CRs; and, if people accept sustainability communications aired by CRs, what happens to their behavioural determinants concerning sustainability; and as a consequence, whether their intention to adopt sustainable behaviours is positively influenced.

This paper begins with a literature review, followed by a description of the methodology and materials. Next, it presents the results generated by SEM analysis and then tests the hypotheses based on the results. In the Discussion section, some example cases from around the world are presented to 
support the current findings. Finally, it provides some conclusions, with implications and directions for future research.

\subsection{The Interrelationships among Sustainability, Unique Media Characteristics (UMCs) of CRs and Sustainability Communications and the Determinants of Intention to Adopt Sustainable Behaviour}

Psychologically, "sustainability" focuses on achieving sustainable well-being of every human being $[54,55]$ concerning environmental, economic, social and cultural perspectives $[1,12,56]$ by promoting enrichment, growth and flexible change [54,55]. Therefore, sustainable development is viewed as a complex and lengthy process of development $[1,12]$. First, environmental sustainability refers to keeping the natural environment fit for humans and other creatures, while satisfying human needs [57]. For environmental sustainability, availability of information and skills for biodiversity conservation, the intention to adapt to climate change and resilience are crucial to rural people [58-61]. Second, economic sustainability indicates increased productivity, the economic efficiency of people's efforts, balanced agricultural and industrial development, and consistent economic growth [12,62-64]; for economic sustainability, dissemination of occupation-relevant developmental information is found to be the most vital resource in third-world countries [64]. Third, social sustainability is a mechanism to ensure multiple aspects of social wellbeing $[4,65]$. By applying democracy at the grassroots level, strengthening local civil society, increasing social cohesion [66-68] and building sustainable capacities in rural areas, amongst other actions, a community can achieve social sustainability [7]. Fourth, cultural sustainability refers to preserving cultural identity, traditions and culturally formed norms $[58,69]$ to bring about a satisfactory intellectual, emotional, moral and spiritual society [69].

To achieve environmental, economic, social and cultural sustainability, the people of a community must have a definite intention to adopt sustainable behaviour [3,5,12,58,62,63,70-73]. Intention, in this regard, is dependent on the way people perceive sustainability (e.g., psychology), their feelings or knowledge relating to sustainability, especially their belief in their ability to make a change or deal with transitions, and other people's influence (i.e., respect and concern for the self and others) on their decisions towards sustainability [74-77]. However, in many developing countries, people have reluctant attitudes, and poor self-efficacy beliefs, as well as normative beliefs about sustainable behaviour $[5,74,75]$. Therefore, these antecedents to intention need to be shaped to create a community involved in the sustainable development process $[5,15]$. Therefore, communication about sustainability in a society mostly derives from knowledge developed through media [56] that needs to be accepted by the rural people. For this, a community requires communication media with a high level of acceptability [78] that can quickly inform, motivate, enable and guide people [75]. However, earlier researchers have found that people's acceptance of a message depends on it coming from a credible source [79] and relating to people's needs and real benefits [66,78,80,81].

The credibility of a source is dependent on how much its orientation matches people's shared values, feelings and sensitivities, and how much its delivery system matches their receptive capabilities, as well as how much a community owns it [78]. No media system meets these criteria more fully than community radio; this two-way community communications medium (third-tier broadcasting) $[8,18]$ is the most trusted and authentic among the rural masses [82]. It gives its listeners access to both the information and means of informing $[24,25,83]$. It provides communications which are consistent and based on the socio-cultural context [5], as well as beneficiary-oriented [7,84]. Community radio targets either a homogeneous or heterogeneous group of rural/urban or marginalised people within a locality or specific geographical area $[7,85]$. It has an extensive reach and is human, interactive, as well as community-focused [82].

Community radio can be availed by any rural community, due to its low costs for infrastructure and program production and distribution compared to any other broadcasting medium [86-93]. This radio station can even be run during a disaster, when other national and private broadcasts are not working [94]. A CR's management is entrusted to a "community radio council", which consists of all the classes of people of a society, including small entrepreneurs, social activists, farmers, fishermen, 
unschooled people, women, youth, ethnic, academics and religious groups [95,96]. Moreover, a modern community radio station, in many countries, is combined with traditional ICTs in telecentres (e.g., computer, internet, telephone, mobile phone and fax), creating an opportunity for disadvantaged people to use the CR station as a training centre for ICTs on a participatory basis $[86,97,98]$. This not only gives the rural people digital touch but also empowers them in terms of information needs to improve their standard of living [99].

In a CR station, people can simultaneously access information, education and entertainment, as well as participate as planners, producers and performers [18,100]. Even in a few countries, enough community participation in radio programming is a legal requirement to continue a community radio [47], which is very unlikely with traditional media. The CRs also have a powerful listeners' club unlike commercial and state-owned radios $[56,100,101]$. The clubs are voluntarily formed groups of local people affiliated to radio stations that support their stations by providing comments on the programs, collecting feedback from other listeners, taking part in program production, performing as a platform for discussion and learning together, spreading positive word of mouth, providing membership fees and collecting donations from community members [102]. Besides the members of a listeners' club, ordinary people can also request special programs and give feedback on the broadcast programs, using emails, mobile phones, and social media, or they can participate in live broadcasting, using mobile phones $[56,100,101]$. The multifaceted involvement of local people in a CR's operation and programs means the communications are free from the influences of government, private organisations, political parties and other institutions $[7,103]$. Additionally, this process makes rural people feel that the messages are dependable and trustworthy, thus fostering acceptance of the broadcast messages by the target population [19,104-107]. In a nutshell, the localism, participatory development and communicative sustainability basis, as well as a different pattern of operation make it a unique community media. Therefore, the first hypothesis to be tested is:

H1: The unique media characteristics of a community radio can positively influence its listeners to accept the sustainability communications it airs.

In principle, rural people have a traditional attitude towards development. They believe that they are developed if they are economically solvent, thus able to identify a solution to a problem within a short time and can consume sufficient goods and service offers [54]. They tend to become self-centred [55]. They hardly consider conservation with growth, and possibly ignore resilience, life in a broad context, or the impact that today's actions can make on tomorrow [54-77]. Therefore, for sustainable development, the way rural people think and feel about sustainability needs to be changed $[5,16,19]$, because a change in attitude is the precursor to behavioural change $[5,108]$. However, changing attitudes through communications involves targeting all the three components of attitudes; namely, cognitive, affective and behavioural/conative aspects [109,110]. Cognitive factors or beliefs refer to the impacts of the availability of information/knowledge on forming an opinion about an object/action; affective factors represent emotions/feelings about the outcome of an action; and the behavioural components constitute commitment or involvement in a decision to act or to work towards the desired outcome [110].

Researchers of communication theories claim that interpersonal interaction and relationships play a vital role in increasing positive feelings towards adopting recommendations in joint decisions regarding an issue needing a solution [79]. As the communications aired by community radios are self-generated, they are accepted by the people of the community without any doubt [103,111,112], and thus influence the affective component of attitude (i.e., feelings about an object). Also, as the real beneficiaries are engaged and empowered in the decisions to communicate [103,111-113], this can increase their commitment to implement them (i.e., the behavioural component of attitude). Moreover, as the discussions in the joint decisions regarding an issue are recorded from the beginning to end and broadcast in the same form, this increases the ability of both the participants and the general audience to evaluate the messages, information and knowledge (i.e., the cognitive component of 
attitude). Attitude is a mental state [114], and the more positive the attitude, the more the positive intention people may have towards certain behaviour $[115,116]$. Therefore, further hypotheses can be proposed:

H2a: People's acceptance of sustainability communications positively influences their attitude to sustainability.

H2b: Positive attitude to sustainability increases community radio listeners' intention to adopt sustainable behaviour.

Besides attitude, a certain level of self-efficacy belief is also important to engage in sustainable behaviour. This is a person's self-perception or belief in their ability to perform a task or bring about a desired outcome [117]. However, through competent communication media, increasing positive expectations of one's performance and the desired outcomes (self and social benefits) of an action [118,119], people's levels of self-efficacy can be improved. Self-efficacy can be increased by communicating multiple causes and consequences of a problem, types of actions and decisions, and how easy it is to take the recommended actions to solve that problem $[79,120]$. Also, communication of positive emotions by famous figures, a role model's success story or peers' experiences about the benefits of a process can increase self-efficacy to engage in that process [121].

Community radios organize participatory programs in different forms [122], where the community's people can take part physically, mentally and emotionally $[103,111,112]$, along with outside experts, to critically analyse a community's multiple problems and solutions from different socio-economic and socio-cultural perspectives at the grassroots level $[24,25,85,122]$. This process of participation may provide psychological feedback to the participants. Moreover, informative, explanatory, demonstrative, storytelling and edutainment-based programs combining scientific and indigenous knowledge $[24,25,85,122]$ can increase self-efficacy by manipulating vicarious experience, expectations of performance outcomes and verbal persuasion.

The self-efficacy of a person is crucial when performing any behaviour that is new or difficult [123], and sustainable behaviour may initially be perceived as a complex behaviour to follow in a given situation in the rural areas. Therefore, people with higher levels of self-efficacy belief are more likely to behave sustainably [117].

Thus, additional hypotheses are proposed:

H3a: If people accept sustainability communications aired by a $C R$, it can positively influence their self-efficacy belief for sustainability.

H3b: Positive self-efficacy belief in sustainability increases community radio listeners' intention to adopt sustainable behaviour.

In addition to attitude and self-efficacy belief, social norms are critical determinants of intention to adopt sustainable behaviour [124]. Social norms are unwritten expected behaviours in a society, community or social group [125]. Social norms include injunctive norms (normative social influence) and descriptive norms (informational social influence) [126] and share a similar meaning to the subjective norm in the theory of planned behaviour [74]. They describe the shared understandings of actions and learnings of what one should do and how to do it in a social system, or following others' good practices [74]. Thus, social norms can be shaped by highlighting individual best practices, summary information about a group, and institutional signals [127].

Social interactions and norm-based communications or persuasive messages enhance normative beliefs or social norms [128]. Media can increase the perceptions of social approval or disapproval through broadcasting news stories on the impacts of a particular behaviour (what one should do and how to do it) and the consequences of policy actions (institutional signals) in society regarding that behaviour [129]. Media create common knowledge through transmitting to other individuals or groups of people what an individual or a group of people already know and what they are currently learning and why; if others participate in a particular action, it changes the norms of why one should do so [130]. Community radios demonstrate one community's members' best practices, the indigenous knowledge of rural people and the scientific knowledge of people from outside the area in 
the form of edutainment-based programs [24,25,85,122]. Moreover, unlike the mainstream media, in the participatory communication of CRs at the radio premises, as well as at the listeners' clubs, the members can easily and freely discuss rights and wrongs [131]. Thus, every member can understand every other member's reactions, government policy and other stakeholders' expectations regarding a social issue $[130,132]$. This, in turn, easily shapes social norms towards positive social change and sustainable development $[74,127,133]$. Hence, two more hypotheses are to be tested, as follows:

H4a: If people accept sustainability communications aired by a $C R$, it can positively influence their social norms in favour of sustainability.

H4b: Positive social norms towards sustainability increase community radio listeners' intention to adopt sustainable behaviour.

\subsection{Hypothesised Model}

Following the literature reviewed, a hypothesized model (see Figure 1) was developed. It is intended to explain the intention of a CR listener to adopt sustainable behaviour. The unique media characteristics of a $\mathrm{CR}$ were assumed as antecedents to the acceptance of sustainability communications by its listeners. Acceptance of sustainability communications was assumed as a cause of change in attitudes, self-efficacy beliefs and social norms, and these, in turn, were assumed as the determinants of adopting sustainable behaviour by the listeners.

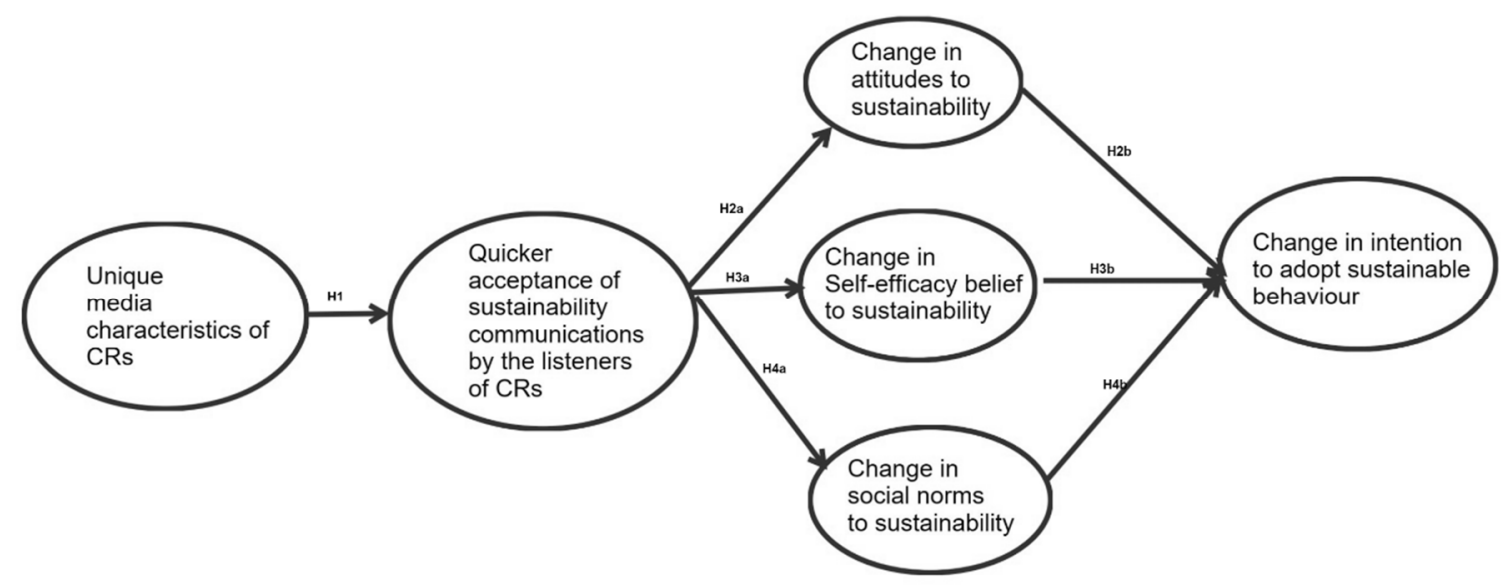

Figure 1. The hypothesised model.

The framework incorporates the basic elements of the theory of reasoned action or theory of planned behaviour $[74,134,135]$ and self-efficacy theory $[118,136,137]$. In this model, social norm is an external factor and its elements (injunctive and descriptive norms) can be influenced by communications $[128,129,138]$. Although attitude is an internal factor, the attitudinal elements (cognitive, conative and affective) are affected by communication interventions [41,42]. Moreover, self-efficacy belief, which combines internal and external factors while deciding on an action, might also be modified by communications $[79,128,139,140]$.

\section{Materials and Methods}

This research uses an explanatory approach because it is the most suitable way to measure the impact of one phenomenon on another and to explain the pattern of relationships between them [141-143]. Because of the unavailability of published quantitative research in the interdisciplinary area of sustainability and community media, the researchers adopted a mixed-method technique, including a focus group discussion to identify and explain questionnaire constructs and items in each construct [144] followed by a questionnaire survey to collect responses on the research problem from a large sample of the target population. 


\subsection{Participants}

The focus group discussion was conducted with radio station managers (three), educated radio program presenters (three) and listeners (four) at the premise of one (i.e., Radio Chilmary in Kurigram District) of the six community radio stations selected for this study. The participants were selected from three different districts based on convenience and judgment of the researchers. The survey was conducted in September 2017. The surveyors randomly approached potential respondents found on the streets, at the marketplaces or their homes within a 10-15 km radius of six CR stations in six districts (i.e., actually the Upazila/subdistrict of Gaibandha, Kurigram, Bogura, Naogaon, Rajshahi and Chapai Nawabganj) in the northern part of Bangladesh. The areas covered by the CRs are poor and underdeveloped compared to other parts of the country. The respondents were asked whether they listen to community radio. Among 400 qualified respondents ( $65 \%$ of them were male), only 306 respondents (i.e., $76.5 \%$ response rate) participated in the survey. However, after collecting the data, the responses from only 300 respondents were included in the final data sheet (i.e., $N=300$ ) as six questionnaires were found to have missing answers.

\subsection{Procedures and Measures}

In the semi-structured session of the focus group, the sustainability communication contents aired by the CRs in Bangladesh were presented before the participants to assist them in understanding the relationship between the "sustainability concept" and behavioural determinants towards sustainability that the CRs can affect. The same contents were also presented in the final questionnaire to assist the respondents in understanding the subject matter. The contents were identified based on a review of the literature on CRs in Bangladesh $[30,32,34,35,37,44,46,48,53,94]$ and classified under the four pillars of sustainability $[4,7,12,56-58,63-66,69]$ (see Appendix A).

During a one-hour discussion, the focus group identified six items to measure the "unique media characteristics", three items each for "acceptance of sustainability communications", "attitudes to sustainability" and "social norms" constructs. It also identified four items to measure "self-efficacy belief" and "intention to adopt sustainable behaviour" constructs, in addition to four items to measure the intention to adopt sustainable behaviour.

Based on the explanations given by the focus group about the constructs and items, with minor changes in wording, a structured questionnaire [145-147] was developed in Bengali, the native language of Bangladesh, to assist the respondents to understand correctly. Two professors of Bengali literature assessed the face validity of the questionnaire, and a pilot test of 100 respondents was conducted in one of the six study districts.

The first section of the questionnaire contained four fundamental listenership questions, which were measured using categorical scale (see Table 1 for items and the scales used to measure them in the questionnaire). The respondents also had to mention their professions/citizen group on the questionnaire. The second part contained questions for testing the hypothesised model and was measured on a five-point Likert scale, which is very popular in social science research [148-150]. 
Table 1. Items used in the questionnaire.

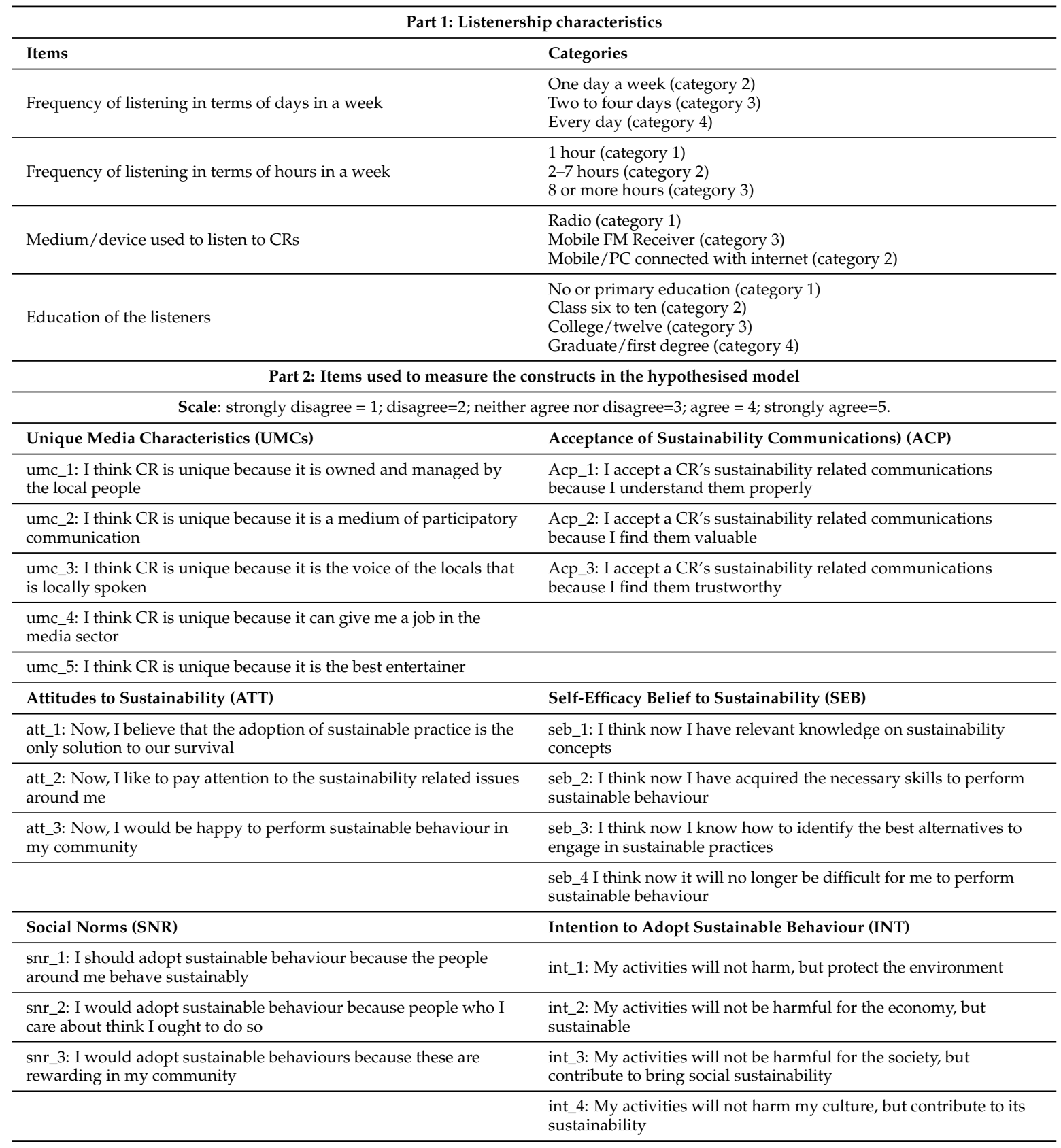

Twelve Master's students from a public university in Bangladesh, voluntarily assisting in the survey, gave explanations of the questions to the less-educated respondents in order to generate more reliable responses and reduce response time. The respondents were asked to provide their contact addresses, professions and signatures on the questionnaire. After the survey, the researcher randomly contacted 150 respondents and found everyone was correctly interviewed as reported by the surveyors that ensured a higher degree of reliability of the survey.

\subsection{Data Analysis}

The researchers used IBM SPSS Statistics for Windows, version 22 (IBM Corporation, August 2013, Armonk, NY, USA) to input the surveyed data and for preliminary analysis. Data on the listenership questions were analysed using percentiles. On the other hand, SEM techniques (confirmatory factor analysis followed by a path analysis) were used to test the hypothesised model, as it is a widely 
used approach by researchers in social science [151-155]. Both partial-least-squares-based structural equation modelling (PLSc-SEM) and covariance-based structural equation modelling (CB-SEM), using SmartPLS 3.0 (SmartPLS GmbH, September 2017, Hamburg, Germany) [156] and AMOS 21 (IBM Corporation, March 2013, Shrinkwrap, USA) [151,157,158], respectively, were used in a single study to compare the model's fit against a number of fit indices to strengthen the statistical soundness of the assessment [42].

\section{Results}

After analysing the surveyed data about the essential listenership characteristics, it was found that a majority of the community radio listeners have the minimum education required to understand the programs (i.e., $68.6 \%$ between six and twelve years of schooling). Most listeners (i.e., $76 \%$ ) use FM receivers in mobile phones to listen to the radio and they listen regularly (i.e., $61.7 \%$ listen eight or more hours per week, $54.8 \%$ listen every day and $35.7 \%$ two to four days per week), and they are not from same citizen group rather they are from diversified backgrounds (See Table 2).

Table 2. Results of the study of basic listenership characteristics.

\begin{tabular}{|c|c|c|c|}
\hline Items & Statistics & Items & Statistics \\
\hline How often is CR being listened to in a week? & \multicolumn{3}{|c|}{ Medium/device used to listen to $C R$} \\
\hline One day a week & $7.7 \%$ & Radio & $13.3 \%$ \\
\hline Two to four days & $35.7 \%$ & Mobile FM Receiver & $76.7 \%$ \\
\hline Irregular & $2.0 \%$ & & \\
\hline How many hours in a week CR is being listened? & & Education Qualification of the Listeners & \\
\hline 1 hour & $6.0 \%$ & No or primary education & $18.0 \%$ \\
\hline 8 or more hours & & Graduate/first degree & $13.3 \%$ \\
\hline \multicolumn{4}{|l|}{ Profession/citizen group of the listeners (participants): } \\
\hline Farmers- & $(20 \%)$ & & \\
\hline $\begin{array}{c}\text { Fishermen, repairers, auto rickshaw pullers and human } \\
\text { rickshaw pullers- }\end{array}$ & $(20 \%)$ & & \\
\hline Tea shopkeepers and other small entrepreneurs- & $(15 \%)$ & & \\
\hline
\end{tabular}

Before measuring the impacts of the variables on one another in the hypothesised model, a confirmatory factor analysis was done using PLSc bootstrapping of SmartPLS software. The results showed (see Table 3) that all the variables were strongly loaded (i.e., between 0.702 and 0.820 ) onto their respective constructs, except two variables of the "unique media characteristics (UMC)" construct (i.e., weakly loaded: umc_04 and umc_05 with 0.149 and 0.138 values, respectively). Therefore, those two variables were not included in the final path analysis. No collinearity problem was found. This is an important quality of a good model based on the SEM approach [157,159-163]. The analysis also showed that the data were normally distributed. The values of the inner (i.e., between constructs) variance inflation factor (VIF) are between 1.00 and 2.00, whereas outer VIF values are between 1.57 and 2.21 (i.e., nor > 5.0) $[162,163]$. 
Table 3. Results of the SEM analysis.

\begin{tabular}{|c|c|c|c|c|c|c|c|c|c|c|c|c|}
\hline \multicolumn{3}{|c|}{ Item-Wise Statistics } & \multicolumn{10}{|c|}{ Construct-Wise Statistics } \\
\hline Items & Loadings & Collinearity Statistics (VIF) & \multicolumn{7}{|c|}{$\begin{array}{l}\text { Discriminant Validity [Fornell-Larcker Criterion and Heterotrait-Monotrait Ratio (HTMT)] } \\
\text { Fornell-Larcker Criterion }\end{array}$} & \multicolumn{3}{|c|}{ Construct Reliability and Validity } \\
\hline umc_1 & 0.756 & 1.782 & & ACP & ATT & INT & SEB & SNR & UMC & CA & CMR & AVE \\
\hline umc_2 & 0.789 & 1.830 & $\mathrm{ACP}$ & 0.775 & & & & & & 0.818 & 0.819 & 0.601 \\
\hline umc_3 & 0.711 & 1.570 & ATT & 0.585 & 0.778 & & & & & 0.819 & 0.821 & 0.606 \\
\hline umc_4 & 0.149 & 1.055 & INT & 0.653 & 0.697 & 0.768 & & & & 0.851 & 0.852 & 0.590 \\
\hline umc_5 & 0.138 & 1.052 & SEB & 0.596 & 0.587 & 0.707 & 0.729 & & & 0.819 & 0.819 & 0.531 \\
\hline acp_1 & 0.767 & 1.838 & SNR & 0.606 & 0.631 & 0.717 & 0.629 & 0.731 & & 0.774 & 0.775 & 0.535 \\
\hline acp_2 & 0.768 & 1.774 & UMC & 0.588 & 0.503 & 0.568 & 0.622 & 0.524 & 0.756 & 0.798 & 0.799 & 0.571 \\
\hline acp_3 & 0.789 & 1.855 & \multicolumn{7}{|c|}{ Heterotrait-Monotrait Ratio (HTMT) and T-values (italic and underlined are T-values) } & $\mathbf{R}^{2}$ & Adj $\mathbf{R}^{2}$ & $f^{2}$ \\
\hline att_1 & 0.814 & 1.982 & ACP & & $\underline{10.09}$ & & $\underline{10.76}$ & $\underline{9.995}$ & $\underline{9.118}$ & 0.346 & 0.344 & $>0.520$ \\
\hline att_2 & 0.810 & 2.067 & ATT & 0.588 & & $\underline{3.348}$ & & & & 0.342 & 0.340 & 0.150 \\
\hline att_3 & 0.706 & 1.614 & INT & 0.653 & 0.700 & & $\underline{3.631}$ & $\underline{2.888}$ & & 0.672 & 0.669 & \\
\hline seb_1 & 0.717 & 1.723 & SEB & 0.595 & 0.585 & 0.708 & & & & 0.355 & 0.353 & 0.179 \\
\hline seb_2 & 0.759 & 1.822 & SNR & 0.607 & 0.632 & 0.717 & 0.629 & & & 0.367 & 0.365 & 0.155 \\
\hline seb_3 & 0.709 & 1.753 & UMC & 0.588 & 0.503 & 0.569 & 0.622 & 0.526 & & & & 0.529 \\
\hline seb_4 & 0.728 & 1.550 & & \multicolumn{6}{|c|}{ Total effects: direct and indirect (path coefficients) } & \multicolumn{3}{|c|}{ Model fit statistics } \\
\hline nrm_1 & 0.760 & 1.657 & $\mathrm{ACP}$ & & 0.585 & 0.566 & 0.596 & 0.606 & & & & 1.000 \\
\hline $\mathrm{nrm} \_2$ & 0.731 & 1.765 & ATT & & & 0.303 & & & & & & $0.025 / 0.025$ \\
\hline nrm_3 & 0.702 & 1.462 & INT & & & & & & & & & 0.021 \\
\hline isb_1 & 0.820 & 2.212 & SEB & & & 0.329 & & & & & & 184.6 \\
\hline isb_2 & 0.766 & 1.881 & SNR & & & 0.319 & & & & $\mathrm{P}$ (prob & ty level) & 0.119 \\
\hline isb_3 & 0.747 & 1.841 & UMC & 0.588 & 0.344 & 0.333 & 0.350 & 0.357 & & & & $0.957 / 0.937$ \\
\hline isb_4 & 0.737 & 1.857 & & & & & & & & & & $0.992 / 0.992$ \\
\hline
\end{tabular}

All items are significant at 0.00 level. Two variables (i.e., umc_4 and umc 5 ) were found with very low loadings and VIF values (bold and italic), therefore haven't included in the path model. Critical ratio (CR) > 3.0; Standard error (SE) <0.1. CA: Cronbach's Alpha; CMR: Composite Reliability; AVE: Average variance extracted. Italic and underlined are T-values. $\mathrm{SRMR}=$ standardized root mean square residual; RMR = root mean square residual; RMSEA = root mean square error of approximation; PCLOSE = closeness of fit; $\mathrm{CFI}=$ comparative fit index; TLI = Tucker-Lewis index; IFI = incremental fit indices; NFI = normed fit index; GFI: goodness-of-fit indices. 


\subsection{Reliability and Validity}

The values of Cronbach's alpha ranged between 0.774 and 0.851. Such high values of Cronbach's alpha ensure excellent consistency in responses across the items within the measure $[142,148,160,164]$. Also, the values of composite reliability or construct reliability of most of the constructs are excellent (i.e., 0.80 threshold) according to SEM researchers [164-166]. Furthermore, the AVE was found to be $>0.50$ (i.e., between 0.531 and 0.606 ), which also ensures convergent validity [161]. In case of discriminant validity, the values of the Fornell-Larcker criterion between constructs ranged between 0.503 and 0.778 , [167]; the coefficients of correlation between the latent constructs were between 0.503 and 0.717 (i.e., not too high -0.90 nor too low- 0.30 ), and the values of cross-loadings suggested by the experts were low (weakly loaded onto irrelevant constructs [168-172]. Moreover, the values of Heterotrait-Monotrait Ratio (HTMT) between the constructs ranged from 0.503 to 0.717 . This ensures the discriminant validity of the data $[154,160,173,174]$. Moreover, the values of standard error (SE) or standardised residuals were $<0.1$, and the critical ratios for all the items were $>3.0$ (based on the covariance-based structured equation approach) or the $T$-values $>1.96$ (i.e., 2.88 and 10.76) between constructs (based on the partial-least-squares-based SEM approach) [164], indicating no possibility of model misfit [157].

\subsection{Hypotheses Test}

The hypotheses of this study were evaluated based on the results of path analysis (i.e., the effect size of one variable on another in total, direct and indirect effects) [152] and the proportion of explained variance (R-squared) of a particular construct $[151,152,160,161,175,176]$ (see Table 3 and Figure 2). In the path model, the effects are the causes of change in one variable due to the presence of or change in another variable [157]. The total effects are equal to the sum of direct and indirect effects, but direct effects are the immediate and unmediated effects of one variable on the others in the model [152]. As the listeners like the characteristics of a $\mathrm{CR}$, their chance of accepting the sustainability communications aired by a CR increased by $58.9 \%$. Also, the unique media characteristics of CRs explain $34.6 \%$ variance ( $R^{2}$ values) in the acceptance of sustainability communications. Thus, the significant impact of UMC on ACP is statistically sound. Thus, the results clearly support the first hypothesis (i.e., H1: The unique media characteristics of a community radio can positively influence its listeners to accept the sustainability communications it airs).

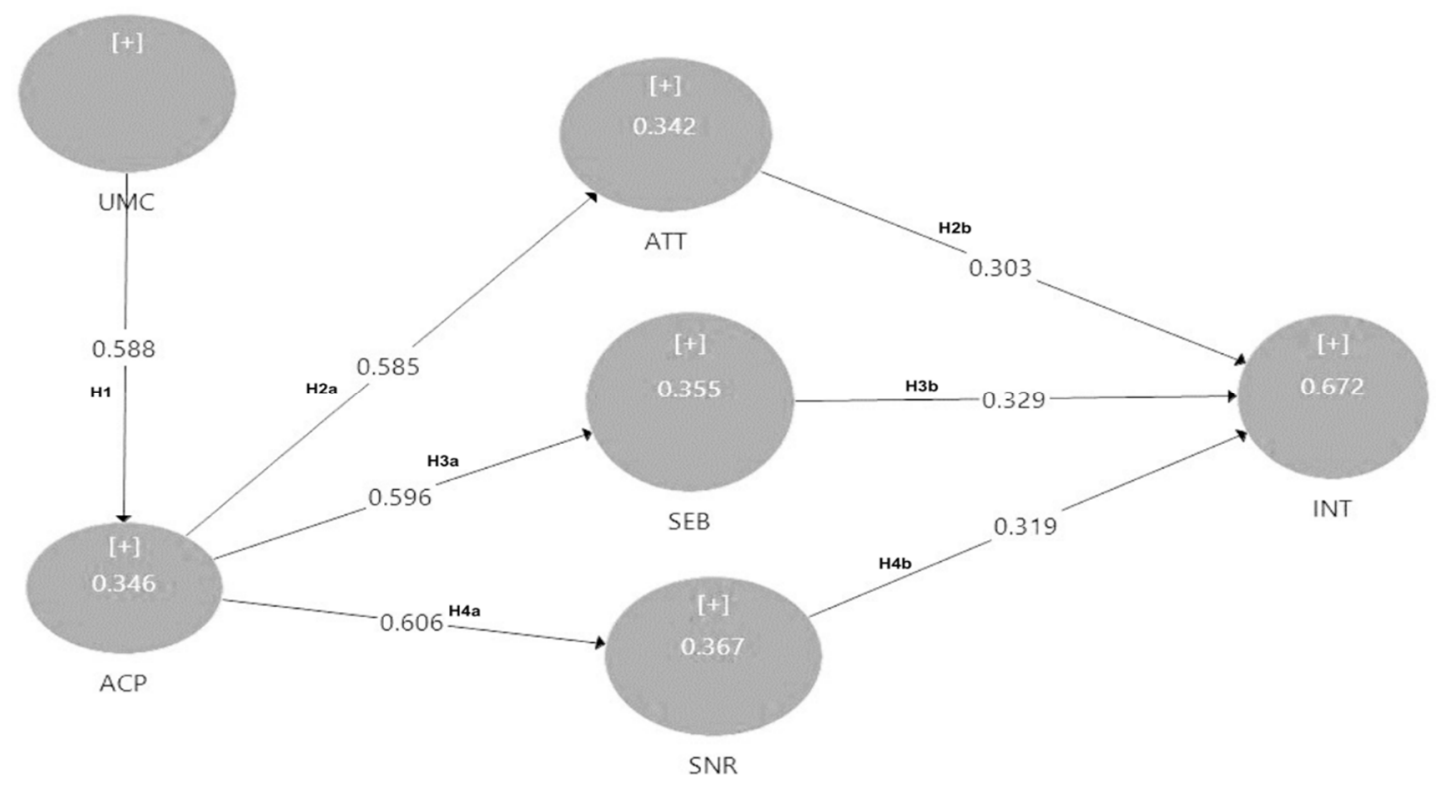

Figure 2. Path model with results. 
Acceptance of sustainability communications by the listeners had a $59 \%$ impact on the probability of bringing about a change in their attitudes toward sustainability. Also, 0.344 or $34.4 \%$ of the variance in attitudes is explained by the acceptance of sustainability communications aired by community radios. Therefore, the significant effects of acceptance of sustainability communications on the listeners' attitudes toward sustainability claims, H2a (people's acceptance of sustainability communications positively influence their attitudes toward sustainability) is confirmed. Moreover, the positive change in attitudes explains $30.3 \%$ of variations in the intention of the listeners to adopt sustainable behaviour. So, $\mathrm{H} 2 \mathrm{~b}$ (positive attitude to sustainability increases community radio listeners' intention to adopt sustainable behaviour) is also confirmed.

When people accept sustainability communications whole-heartedly, not only do their attitudes toward sustainability change, but their levels of self-efficacy belief also improve. The level of self-efficacy belief of these community radio listeners is improved by $59.6 \%$ if they are exposed to sustainability communications regularly. Also, acceptance of sustainability communications explains $35.5 \%$ of the variance in self-efficacy. So, due to the changes in their level of self-efficacy, their intention to adopt sustainable behaviour is also increased. The study found that self-efficacy belief leads to $32.9 \%$ intention of the rural people to engage in sustainable behaviours. Moreover, the strength of structural relationships between acceptance of sustainability communications and self-efficacy belief in relation to sustainable behaviour is 0.355 . Therefore, based on the size of effects and strength of relationships between the constructs, hypotheses H3a (if people accept sustainability communication aired by a CR, it can positively influence their self-efficacy belief for sustainability) and H3b (positive self-efficacy belief in sustainability increases community radio listeners' intention to adopt sustainable behaviour) are confirmed.

In addition to attitudes and self-efficacy belief, people's social norms in relation to sustainable behaviour are significantly affected by how much people accept sustainability communications. The study found that, if people accept sustainability communications, their social norms will be positively changed by $60.6 \%$, which results in $31.9 \%$ change in intention to adopt sustainable behaviour. Also, the coefficient of determination, or the proportion of variance (\%) that the acceptance of sustainability communications can explain in social norms is $36.7 \%$. Therefore, based on the effect size and strength of relationships, hypotheses $\mathrm{H} 4 \mathrm{a}$ and $\mathrm{H} 4 \mathrm{~b}$ are also said to be supported. Moreover, attitudes, self-efficacy belief and subjective norms (the endogenous variables) substantially explain the variance $(67 \%)$ in the intention to adopt sustainable behaviour (dependent variable).

The study also found that acceptance of sustainability communications (ACP) affects attitudes, self- efficacy belief, and social norms at similar levels (i.e., 0.585, 0.596, 0.606 respectively). These, in turn, affect intention to adopt sustainable behaviour, also at similar levels $(0.303,0.329,0.319$, respectively). In this regard, the independent variable and the endogenous variables have less indirect effects but more direct effects on other variables. Moreover, the coefficient of determination or the proportion of variance explained in the endogenous latent variables are also almost similar (i.e., acceptance of sustainability communications 0.346 , attitude to sustainability .342 , self-efficacy belief to sustainability 0.355 , and social norms to sustainability 0.367 ). This evidence supports the equal importance of attitudes, self-efficacy belief and social norms as three behavioural determinants in the model, where the aim is to measure the impact of sustainability communications via community radios.

\subsection{Model Fit Indices}

The structural model fits the data very well, based on a number of model fit indices. The value of $\chi^{2}$ (Chi-square) of the model is low (184.6) compared to the degrees of freedom (163) in CB based SEM analysis with $p=0.119$. The value of standardized root mean square residual (SRMR) in PLS-SEM is 0.025 and the value of root mean square residual (RMR) is also 0.025 . Additionally, the value of root mean square error of approximation (RMSEA) in CB-SEM is 0.021, which is well below the cut-off criteria of $<0.07$ [177-179] or $<0.06$ [160,170-172]. Moreover, the value of criteria for the closeness of fit (PCLOSE) is 1.000 (i.e., >0.50) [151]. Furthermore, the values of the comparative fit index (CFI), 
Tucker-Lewis index (TLI), incremental fit indices (IFIs), and normed fit index (NFI) are $>0.95$. Also, the value of goodness-of-fit statistic (GFI) (0.937) is close to 0.95 and much higher than RMR (0.025), which indicate a very good model fit [171].

\section{Discussion}

This research has found that the listeners of a community radio perceive that the sustainability communications aired by the $\mathrm{CR}$ can increase their self-efficacy belief regarding a development issue. Communications by community radio can influence the sources of self-efficacy belief $[24,25,85,122]$. For example, CRs organise many-to-many discussions or demonstrations, where people of different backgrounds can participate to share indigenous and modern knowledge on developmental issues $[104,105,122]$. In this way, ordinary people's level of confidence to learn from other community members or share sustainability matters with them, or persuade them to engage in sustainable behaviour, can be increased. Through broadcasting a community's unity or ambitions (courageous speech or voice) to make a change towards sustainable development, the general public can be verbally persuaded. By listening to the success stories or performances of someone similar to themselves or their neighbours, the listeners' self-efficacy belief can be improved through vicarious experience. Through highlighting current capabilities or creating a dream or imagination of future benefits, the expectations of performance outcomes can be increased [118,119].

Increased self-efficacy belief influences local people to explore the opportunity and use their capabilities to engage in a sustainable process. For example, it has been found practically that Radio Mukti improved riverside people's knowledge and built capacity for sustainable fishing through broadcasting dialogues between experts and local fishermen, whereas, before the program, they felt that it would be quite impossible for them [44].

Community radio, by broadcasting storytelling by local fishmongers, farmers, mat weavers, petty traders and hunters of the Obane community, on what to do and how to do it, in the local melodious traditional chorus, improved the levels of self-efficacy of local communal labourers to engage in the $10 \mathrm{~km}$ dredging project in the Luhue River (that had remained a curse for 40 years) [180]. The radio regularly announced the schedule of participation in the work and names of those who had already participated, and this motivated the broader community to quickly finish the dredging project to prevent the river from choking. This also enabled them to maintain the normal ecological processes and ultimately to sustain flora and fauna, as well as revive economic life and restore the community as a food basket [180].

At Ziniaré in central Burkina Faso, Radio Yam Vénégré, by broadcasting a series of 45-minute radio magazine programs based on recordings of the community members' best practices, their indigenous knowledge and simple techniques from every corner of the villages, vastly enabled the local people to prevent soil degradation, deforestation and water waste [181,182].

Community radios contribute to bringing economic sustainability to the farmers through knowledge-building programs. These examples strengthen the researchers' claim that communication interventions via CRs change the listeners' levels of self-efficacy belief, and because of that, they can engage in sustainability practices.

Moreover, unlike the mainstream media, through participatory communications (i.e., conversations) at the radio premises or at the listeners' clubs and live phone-ins, the members can easily and freely debate on the rights and wrongs regarding a social issue or government policies. Thus, the community's people understand each other's expectations and reactions about an issue [130], either by directly participating in the conversations or by listening to the live broadcasts. Such direct interactions of community members with the communications initiated by community radio easily shape their social norms regarding sustainability. For example, "Radio Padma", by airing talk shows (by experts, social activists, local women journalists, youth, and members of listener clubs) on women's empowerment positively shaped the social norms of both the young and older people [183-187]. Consequently, they later started protesting Eve-teasing, acid crimes, gender inequalities and other such 
unsustainable social behaviours in rural areas in Bangladesh [183]. Moreover, Radio Ada and Shimly radio in Ghana affected the listeners' social norms about what they should and should not do to keep the local culture alive in a community, through organising drama and storytelling in very original style. Such programs were so influential that the local youth enthusiastically started practicing local chorus, music and comedies in all social gatherings [104], whereas those who were fond of modern music had previously almost forgotten the root of their own culture [188].

In any research based on SEM, the results regarding reliability and validity criteria, model fit indices mentioned by the experts and the effect size of one variable on the others are critical to evaluating the quality of a model [161-163,169-171]. Therefore, unlike many other sustainability researchers, who compare a model just against a couple of indices, we have used both the PLS-SEM and CB-SEM to compare our model's fit against many indices. The study reveals a normally distributed dataset with no collinearity problem and above-accepted range of values of Cronbach's alpha [189], average variance extracted and T-values (critical values), and with high levels of reliability and validity for the hypothesised model.

The values of some indices generated by PLSc-SEM and CB-SEM are not very different. The study found a low value of $\chi^{2}$, which indicates a low level of discrepancy between the sample and fitted covariance matrices $[172,190]$. The chance of getting such an integrated model, in reality, is very high (there is over $11 \%$ chance; $p$-value $0.119>0.05$ ), whereas many researchers ignore this important index [171,172].The values of standardised root mean square residual (SRMR) and root mean square residual (RMR), generated by PLS-SEM and CB-SEM, respectively, are the same, which is unusual in many pieces of research, and indicates perfect goodness-of-fit of our model [161,191]. Moreover, according to many SEM researchers (e.g., [153,158,160,171,172,190]), the high values of other fit indices (i.e., >0.95) indicate an excellent model fit.

In this socioeconomic behavioural study, the substantial influence $(>0.30$ to 0.60$)$ of the latent constructs on each other (i.e., direct and total effects: insignificant indirect effects, but greater direct effects) and moderate to high levels of strength of relationships $\left(R^{2}>0.20\right)[159,192]$ among them are realized (values between 0.342 and 0.672 ). The study shows that sustainability communications broadcast over community radio services affect over $50 \%$ of current levels of attitudes, self-efficacy beliefs and social norms, which in turn results in significant (or moderate) positive changes in intentions to adopt sustainable behaviours among rural people in developing countries.

Although many researchers found that the impact of communications on the antecedents to intention to adopt sustainable behaviour varied [16,41,193], the current research found something different. Due to the unique media characteristics of community radio, sustainability communications aired by community radio services affect people's attitudes, self-efficacy beliefs and social norms simultaneously at a very similar level; these, in turn, affect their intention, also at very similar levels, to adopt sustainable behaviour. Therefore, this research proves that, in order to change rural people's behaviour towards sustainability through communication interventions by $\mathrm{CR}$, they should be designed in such a way as to include such communication elements that simultaneously target attitudes, self-efficacy beliefs and social norms.

The current research has found that community radio services are becoming very popular in Bangladesh, as in many other developing countries [53,194-196]. In five years, the CRs have covered $30 \%$ of the total population in their broadcasting area in Bangladesh [53]. Although Bangladesh is a developing country, the mobile penetration rate is very high, (i.e., subscriber penetration is growing over $40 \%$ per year) [197]. A substantial number of mobile phone users are now found even in the rural areas [198], and among them $76 \%$ use an FM receiver to listen to CRs and to access over 480 different programs per week [197]. Thus, people listen to CRs from their workplaces, listeners' clubs, and while they travel $[53,199]$. The current listener groups are engaged in many semi-skilled jobs, including small enterprises, retail shops and farming, which comprises the majority of rural youth, who potentially can contribute a lot to sustainable development in the rural areas $[53,200]$. 
This research found the second reason to be that people like the CRs, neither because they may get jobs in the media sector (i.e., item no, uc_ 5 with insignificant value) nor because CRs entertain people better than any other media (i.e., item no. uc_6 with negligible value) (See Table 1 for the items), but because CRs represent the opinions and interests of the ordinary people [94]. Community radios are the only media where poor and disadvantaged people are empowered to participate in the communication process $[66,201]$ and they control the means of communication (way of delivery) $[8,23,89,192]$. These characteristics enhance CRs' familiarity, credibility and integrity to local people [202-205], so it removes any doubt about the communication interventions and enhances the trustworthiness of the aired messages [181].

Moreover, from a social perspective, $\mathrm{CR}$ is a medium of peace that nurtures multiple languages and preserves the diversified heritage of the world, as well as observing the values of the International Development Community of the United Nations (i.e., peace, inclusion, equity and accountability) at the roots of sustainable development [90,206-208]. Thus, people find that community radio is a trusted and true development partner and so they accept it for social, economic, environmental and cultural sustainability communications. Therefore, the researchers' claim that the unique features of CR influence the rural people to accept sustainability communications through this medium has been found statistically and theoretically sound.

The communication intervention of community radio is initiated by a participatory communication process, where people's direct involvement creates an opportunity to evaluate any decisions regarding sustainability. Also, such involvement increases emotional attachment and behavioural commitment, thus affecting all the components of attitudes of the participants. Moreover, the CRs broadcast real discussions and dialogues as those happen in participatory communication; as a result, the broader community feel the same way as the participants do in the communication production, and therefore, their attitudes to sustainability can be easily influenced [68,103,111,112]. For example, in Bangladesh, it has been found that community radios have changed the attitudes of people living near the coast to climate change and human-made disasters through broadcasting relevant programs $[185,209,210]$.

Researchers report that over 75\% of listeners of "Radio Nalta" in the Satkhira District in Bangladesh agreed that, after listening to the environmental programs aired by the radio, their traditional attitudes to temperature rise, soil infertility, river erosion and salinity in the locality had changed [210]. Radio Mukti has changed riverside people's attitudes to human-made disasters, river erosion and scarcity of fish [44]. Oltoilo Lemaa community radio in Kenya, with its self-initiated programs (i.e., broadcasting dialogues among experts, local government authorities and ordinary people on human and wildlife relationships from various points of view) has changed local people's attitudes to wildlife preservation and management of natural resources $[19,56,92]$, whereas before the intervention, the local people thought that the forests and wildlife were assets of government, not of the locals [92]. Such changes in attitudes led to positive intention to reduce hunting and deforestation dramatically in that region $[19,92]$.

\subsection{Implications}

This research can inspire and guide interdisciplinary researchers from rural society, community radio, and sustainability communication areas, as well as other development stakeholders, to contribute more to the sustainable development of the rural communities. However, to harvest the benefits of CRs in sustainability communications, the interveners need to identify the strengths of CRs, participate in dialogues with the local people or sit with them to initiate the most appropriate methods of communication. The regional accent and local language must be used in all the development contents to be communicated. The messages should be based on sustainability themes with authentic, rational appeal and should be executed using slice-of-life, authoritative, demonstration and informative execution styles, and should target all the components of behavioural determinants simultaneously, as discussed above. 
Policymakers can apply the CRs positively to contribute to achieving the 2030 agenda for sustainable development (Sustainable Development Goals). They may use this different medium to bring changes in attitudes, improve levels of self-efficacy belief and positively shape the levels of social norms of the rural masses through multiple communication interventions. Community radios can be widely used to develop skills among the rural masses, based on indigenous and modern knowledge, to assist them in securing alternative incomes, sustainable farming, and small business promotion to increase opportunities for self-development and poverty eradication. Through initiating dialogues between the stakeholders and broadcasting those along with experts' opinions, CRs can easily engage listeners in waste management, renewable energy, natural resource preservation, water management, forest and mountain management, wildlife management and land management.

The CRs can be used to disseminate climatic information (e.g., early weather warnings, adoption of new methods of cultivation and cropping patterns, preparedness for disaster, risk sharing due to climate change, etc.) in remote areas, even when electricity is not available. Through organising multiple cultural programs with indigenous design and delivering them in a community's most accessible way, a CR may efficiently transmit traditional cultural values and explore root culture and nurture to protect it. Moreover, CRs can be applied to bring social sustainability in developing countries where social cohesion is crucial. Some well-developed programs can contribute to diffusing gender equality (e.g., women's empowerment, rights to gender, etc.), social well-being (e.g., elimination of eve-teasing, gambling, dowry, etc.), resource sharing as well as accountability of the government authorities (e.g., transparency, rules and regulations, etc.).

Moreover, from methodological points of view, young researchers in the sustainability communication and media interdisciplinary arena may learn how to conduct a focus group discussion, develop a structured interview questionnaire, and use both covariance-based SEM and partial-least-squares-based SEM with the same dataset. They would also learn about how to interpret reliability, validity and other critical issues of an SEM-based model. This research also guides people on how to interpret the impacts of the variables in a path model and model fit indices towards building a theoretically and statistically sound model in the world of communication.

\subsection{Limitation and Directions for Future Study}

Although the study shows excellent potential for using CRs for sustainable development based on an integrated model, it has a few limitations. The impact of CRs on the rural people regarding their intentions to adopt sustainable behaviour is measured based on the opinions of the respondents in the form of a structured interview questionnaire, not a self-administered questionnaire, due to the variation in literacy among the participants. Although the interview was recorded using a mobile phone and the authenticity of interviews was checked later by phoning the respondents, in the future, a self-administered questionnaire survey can be conducted. Moreover, in the case of the structured model, only attitudes, self-efficacy belief and social norms were used as determinants of intention to adopt sustainable behaviour; other factors, for example, "ethical obligation and motivation" as internal, as well as "opportunity to explore" as an external factor, might be examined as mediators $[75,76,85,211]$. No observations or experiments were carried out to verify whether the perceived changes in the intentions of the rural people were due to the intervention of the community radio itself or not. Furthermore, no open-ended questions were used in the survey. Therefore, in the future, a modified questionnaire combining both closed-ended and open-ended items with detailed demographic variables can be used. Also, the survey did not include the characteristics of non-CR listeners and had the data of only CR listeners. In sustainable issues, the non-CR listeners can be important in some cases, especially in sustainable behaviour that can rather be an area of future research as a comparative study.

Experimental design can be applied to verify the findings of the current study. In particular, a district or a few districts or a few villages can be selected, then their current level of sustainability practices can be recorded. Afterwards, some sustainability interventions can be taken by a community 
or their representatives or policymakers through CRs for a specific period, and, either after or during the intervention campaigns, rural people's change in attitudes, efficacy beliefs, social norms and intentions can be measured and compared with their pre-intervention status. Thus, possibly the real impact of the CRs on the rural communities regarding their intentions to adopt sustainable development processes can be fully realized, and a model finalised for use in this regard all over the world.

\section{Conclusions}

It was found that people do not primarily like CRs as a source of entertainment, but as a medium of participatory communication that works as the voice of the locals and is owned and managed by local people. Therefore, people find it reliable or dependable. Due to these unique media characteristics of CRs, people find the aired communications are easy to understand, valuable and trustworthy, so they accept them whole-heartedly. Therefore, changes are realised in people's attitudes (belief in sustainability, like to learn, love to perform), self-efficacy belief (knowledge, skills, confidence) and subjective norms (other people do, approval, reward), and they engage in environmental, economic, social and cultural sustainability actions in their daily life.

Effective sustainability communications are necessary to engage rural people to adopt sustainable actions. However, this research has found that rural people perceived that no communication media other than community radio could be the most effective intervener. The researcher has drawn a hypothetical model derived from a focus group discussion that was backed up by the literature reviewed. Both covariance-based SEM and partial-least-squares-based SEM were applied to analyse the collected data from 300 (as entered in the final data sheet) respondents, and the model was found to be sound, based on the global goodness of fit criteria.

Although the research was conducted in Bangladesh, the results of the research are in line with many previous case studies on community radios in other parts of the world. Therefore, community radios can easily be used by development agents in all developing nations, including both public and private sector stakeholders. Lastly, through broadcasting participatory-based communications on sustainability issues concerning a specific context, $\mathrm{CRs}$ can vastly contribute to sustainable development.

Author Contributions: Conceptualization, M.S.; Formal analysis, M.S.; Methodology, M.S.; Resources, A.H.; Software, M.S.; Supervision, A.H.; Validation, A.H.; Writing-original draft, M.S.; Writing-review \& editing, A.H. and M.S.

Funding: This research did not receive any external funding.

Acknowledgments: The authors would like to thank all the respondents and community radio managers who participated in the focus group discussions and survey, as well as the surveyors (student). Also, we are grateful to the reviewers for their valuable comments.

Conflicts of Interest: The authors declare no conflict of interest. 


\section{Appendix A}

Table A1. Based on a review of the studies on CRs done in Bangladesh $[30,32,34,35,37,44,46,48,53,94,185-187,195,196]$ the sustainability issues under the four pillars of sustainability that broadcasted by the community radios in Bangladesh were presented in the second part of the questionnaire (translated from Bengali).

Social issues: Rights of child, adolescent, marginalised, disabled, fishermen, street children, women and girls, senior citizens; rights to information; citizen rights and responsibilities; gender equality, women's empowerment; protesting dowry, drugs, child marriage, tobacco, alcohol, human trafficking, acid crime, Eve-teasing; child and mother nutrition, child mortality, healthy cooking, health education, reproductive health; safe migration; religious norms, morality, and superstitions, wellbeing, peace; access to law and justice; issue-based development programs through local language, local government administration/governance, NGO service delivery news, public service announcements; preschool education; and school-based entertainment; local personalities.

Environmental issues: Local biodiversity and environmental best practices; early disaster warning and post-disaster risk reduction, rehabilitation; adaptation to climate change; river erosion, river filling, tree plantation, mountain keeping and deforestation; sustainable land use and management; neighbourhood cleanliness, water, and sanitation, open defecation; renewable energy: biogas and solar, use of energy saving equipment; jute-made goods vs plastic.

Economic issues: Local small and successful entrepreneurship; guidance on: poultry, fisheries, livestock, agricultural produce and preservation, opportunities for exports, crop rotation, family farming, sustainable irrigation; market/price, alternative income generation opportunities; ICTs for development; job information; career show; vocational and technical education for early career; youth development; English language for better career; overseas employment opportunities; handicraft; small and cottage industry news; development motivation.

Cultural issues: Entertainment in local dialects-traditional songs, drama, theatre; local art and crafts, local life and livelihood; indigenous cultural knowledge and language of marginalised people; local literature, poetry/poets, singers, artists; local history and liberation war; local sports, heritage, and tourism; national, local and religious festivals; local fashions and cooking; western culture vs local culture; special day celebration; life of celebrities.

\section{References}

1. Burja, C.; Burja, V. Sustainable development of rural areas: A challenge for Romania. Environ. Eng. Manag. J. 2014, 3, 1861-1871. [CrossRef]

2. United Nations. The Sustainable Development Goals Report 2016. Available online: https://read.un-ilibrary. org/economic-and-social-development/the-sustainable-development-goals-report-2016_3405d09f-en\#page1 (accessed on 12 December 2018).

3. WCED. Our Common Future; Oxford University Press: Oxford, UK, 1987.

4. Harris, J.M. Sustainability and sustainable development. Int. Soc. Ecol. Econ. 2003, 1, 1-12.

5. UNEP. Communicating Sustainability: How to Produce Effective Public Campaigns; United Nations Environment Programme: Paris, France, 2005.

6. Mefalopulos, P. Communication for sustainable development: Applications and challenges. In Media and Glocal Change. Rethinking Communication for Development; Hemer, O., Tufte, T., Eds.; CLACSO: Buenos Aires, Argentina, 2005; pp. 247-260.

7. Mefalopulos, P. Development Communication Sourcebook. Broadening the Boundaries of Communication; World Bank: Washington, DC, USA, 2008.

8. Wete, F.N. Mass communication and development: Impact depends on strategies. Afr. Media Rev. 1988, 3, 34-45. [PubMed]

9. Gregory, S. An Assessment of the Role of Community Radio in Peacebuilding and Development: Case Studies in Liberia and Sierra Leone. Search for Common Ground, 2009. Available online: http:/ /www.sfcg. org/articles / An-Assessment-of-the-Role-of-Community-Radio.pdf (accessed on 17 December 2017).

10. Daly, H.E. Beyond Growth: The Economics of Sustainable Development; Beacon Press: Boston, MA, USA, 1996.

11. Petty, R.E.; Cacioppo, J.T. Communication and Persuasion: Central and Peripheral Routes to Attitude Change; Springer: New York, NY, USA, 1986. 
12. Basiago, A.D. Economic, social, and environmental sustainability in development theory and urban planning practice. Environmentalist 1999, 19, 145-161. [CrossRef]

13. Sood, S.; SenGupta, M.; Mishra, P.R.; Jacoby, C. Come Gather Around Together: An Examination of Radio Listening Groups in Fulbari, Nepal. Gazette 2004, 66, 63-86. [CrossRef]

14. Hedlund-de, W.A. Exploring worldviews and their relationships to sustainable lifestyles: Towards a new conceptual and methodological approach. Ecol. Econ. 2012, 84, 74-83. [CrossRef]

15. Godemann, J.; Michelsen, G. Sustainability Communication-An Introduction. In Sustainability Communication: Interdisciplinary Perspectives and Theoretical Foundation; Godemann, J., Michelsen, G., Eds.; Springer: Dordrecht, The Netherlands, 2011; pp. 3-11.

16. Newig, J.; Schulz, D.; Fischer, D.; Hetze, K.; Laws, N.; Lüdecke, G.; Rieckmann, M. Communication regarding sustainability: Conceptual perspectives and exploration of societal subsystems. Sustainability 2013, 5, 2976-2990. [CrossRef]

17. Vatikiotis, P. Democratic Potentials of Citizens' Media Practices. In Understanding Community Media; Howley, K., Ed.; Sage Publications: London, UK, 2010; pp. 32-40.

18. Berrigan, F.J. Community Communications: The Role of Community Media in Development; UNESCO Press: Paris, France, 1979.

19. Ochichi, J.P. An Assessment of Community Radio in the Context of Rural Development in Kenya. Ph.D. Thesis, University of Nairobi, Nairobi, Kenya, 2014.

20. AMARC. Community Radio Social Impact Assessment Removing Barriers Increasing Effectiveness. World Association of Community Radio Broadcasters. 2007. Available online: http:/ / www.ictregulationtoolkit. org/action/document/download?document_id=3465 (accessed on 12 December 2018).

21. Manyozo, L. Mobilizing rural and community radio in Africa. Ecquid Novi 2009, 30, 1-23. [CrossRef]

22. Wilkinson, C. On the same wavelength? Hyper diverse young people at a community radio station. Soc. Cult. Geogr. 2017, 1-15. [CrossRef]

23. Mtimde, L.; Bonin, M.; Maphiri, N.; Nyamaku, K. What Is Community Radio? A Resource Guide; AMARC Africa and Panos Southern Africa: Johannesburg, South Africa; Lusaka, Zambia, 1998.

24. Fraser, C.; Estrada, R.S. Community Radio for Change and Development. Development 2002, 45, 69-73. [CrossRef]

25. Gaynor, N.; O'Brien, A. Community radio, democratic participation and the public sphere. Irish J. Sociol. 2017, 25, 29-47. [CrossRef]

26. Noronha, F. Community Radio-Singing Tunes in South Asia. Econ. Political Wkly. 2003, 38, $2168-2171$.

27. Vyas, B.P. 4 Women Who Are Using Community Radio to Bring Change in Rural India. The Better India, 2015. Available online: https:/ / www.thebetterindia.com/22023/women-community-radio-rural-india/ (accessed on 21 December 2017).

28. Myers, M. Voices from Villages: Community Radio in the Developing World: A Report to the Center for International Media Assistance; Center for International Media Assistance: Washington, DC, USA, 2011.

29. Hussain, F.; Tongia, R. Community Radio for Development in South Asia: A Sustainability Study. In Proceedings of the International Conference on Information and Communication Technologies and Development, Bangalore, India, 15-16 December 2007; pp. 260-272.

30. Khan, M.A.A.; Khan, M.M.R.; Hassan, M.; Ahmed, F.; Haque, S.M.R. Role of Community Radio for Community Development in Bangladesh. Int. Tech. Mgt. Rev. 2017, 6, 94-102. [CrossRef]

31. Titumir, R.A.M.; Rahman, K.M.M. Poverty and Inequality in Bangladesh Unnayan Onneshan-The Innovators; Centre for Research and Action on Development: Dhaka, Bangladesh, 2011.

32. Sen, A. Community Radio in Bangladesh-Including the Excluded. UNESCO Chair on Community Media, 2015. Available online: http://uccommedia.in/news/community-radio-in-bangladesh-including-theexcluded/ (accessed on 28 October 2017).

33. Busolo, D.N. Assessing Sustainability of Rural Community Radio in Kenya: Case Study of Radio Mangelete. University of Nirobi. 2013. Available online: http://erepository.uonbi.ac.ke/bitstream/handle/11295/ 94085/Busolo_Assessing\%20Sustainability\%20Of\%20Rural\%20Community\%20Radio\%20In\%20Kenya\% 20Case $\% 20$ Study\%20Of\%20Radio\%20Mangelete.pdf? (accessed on 28 October 2017). 
34. Rahman, A.H.M.B. SDGs Implementation Review (SIR) Report: Community Radio Broadcasting for Empowering Rural People for Achieving the UN Sustainable Development Goals (UN SDGs) in Rural Bangladesh. On the Eve of National Conference on SDGs Implementation Review 2018 Prime 4-6 July 2018, Minister's Office Government of the People's Republic of Bangladesh Dhaka Bangladesh. Available online: https:/ / sustainabledevelopment. un.org/content/documents/20567BNNRC.pdf (accessed on 6 December 2018).

35. Rahman, A.H.M.B. Role of Community Radio for Achieving Millennium Development Goals (MDG) in Rural Bangladesh. The Media Development Network. 2013. Available online: http:/ / www.comminit.com/media-development/content/role-community-radio-achieving-millenniumdevelopment-goals-mdg-rural-bangladesh (accessed on 14 December 2017).

36. UNESCO. Community Media Sustainability Policy Series. Available online: https://en.unesco.org/ community-media-sustainability/policy-series/defining (accessed on 10 January 2019).

37. Baker, S. Bangladesh Community Radio: Hello Red Crescent-We Listen to You. Global Disaster Preparedness Center. IFRC. 2016. Available online: https:/ / www.preparecenter.org/resources/bangladeshcommunity-radio-hello-red-crescent-\%E2\%80\%93-we-listen-you (accessed on 14 December 2017).

38. Bearth, T. Language and Sustainability. In The Role of Languages for Development in Africa: Micro and Macro Perspectives; Beck, R.M., Ed.; Rüdiger Köppe: Cologne, Germany, 2013; pp. 15-61.

39. Bearth, T.; Beck, R.M.; Döbel, R. Communicative Sustainability: Negotiating the Future from the Periphery; LIT Verlag GbmH \& Co. KG Wien: Zurich, Switzerland, 2017.

40. Döbel, R. Evaluating Communicative and Environmental Sustainability-An Approach to Collaborative Self-Evaluation. EASY ECO Conference: Improving the Quality of Sustainable Development Projects. University of Saarland, Center for Evaluation, 11-14 October 2006. Available online: http:/ / www.wuwien. ac.at/inst/fsnu/saarbruecken/papers/abstracts/Doebel.pdf (accessed on 10 January 2019).

41. Servaes, J.; Lie, R. New challenges for communication for sustainable development and social change: A review essay. J. Multicult. Discourses 2015, 10, 124-148. [CrossRef]

42. Shahzalal, M.; Font, X. Influencing altruistic tourist behaviour: Persuasive communication to affect attitudes and self-efficacy beliefs. Int. J. Tour. Res. 2018, 20, 326-334. [CrossRef]

43. Brulle, R.J. From Environmental Campaigns to Advancing the Public Dialog: Environmental Communication for Civic Engagement. Environ. Commun. 2010, 4, 82-98. [CrossRef]

44. Morshed, S.M. Role of Community Radio in Disaster Risk Reduction: Learning from Field Experiences in Bangladesh. BNNRC, 2017. Available online: http:/ / bnnrc.net/bnnrc-publications (accessed on 20 October 2017).

45. The AIMS Team. 13 February: Happy 2017 World Radio Day to All! FAO. 2017. Available online: http://aims.fao.org/activity/blog/13-february-happy-2017-world-radio-day-all (accessed on 13 December 2017).

46. Genilo, J.W.; Bhowmick, B.C.; Hossain, M.S. Communicating Radio in Bangladesh. Giving Voice to the Voiceless. In Media Studies and Journalism Policy. Brief; University of Liberal Arts: Dhaka, Bangladesh, 2016.

47. Girard, B. Empowering Radio; World Bank Institute: Washington, DC, USA, 2007.

48. Anwar, M. Women's Participation in Community Radio in Bangladesh. Master's Thesis, The University of Guelph, Guelph, ON, Canada, 2015.

49. Balan, K.C.S.; Norman, S.J. Community Radio (CR)—Participatory Communication Tool for Rural Women Development-A Study. Int. Res. J. Soc. Sci. 2012, 1, 19-22.

50. Nafiz, A.Z. Reaching the Community through Community Radio-Readjusting to the New Realities: A Case Study Investigating the Changing Nature of Community Access and Participation in Three Community Radio Stations in three Countries, New Zealand, Nepal and Sri Lanka. Ph.D. Thesis, University of Canterbury, Christchurch, New Zealand, 2012.

51. Wood, C.E. Engaging Communities with Farm Radio in Malawi. 2010. Available online: http:/ / dspace.col. org/bitstream/handle/11599/2128/2010_WoodCE_Farm_radio_Malawi.pdf?sequence=1\&isAllowed=y (accessed on 6 October 2017).

52. Sharma, A.; Kashyap, S.K. Community radio: A community media module for empowerment of rural women. Media Asia 2015, 42, 180-191. [CrossRef]

53. Hassan, S.K.; Rahman, A.H.M.B. Why Community Radio Matters in Bangladesh? BNNRC: Dhaka, Bangladesh, 2016.

54. Di Fabio, A. The psychology of sustainability and sustainable development for well-being in organizations. Front. Psychol. 2017, 8, 1534. [CrossRef] 
55. Di Fabio, A. Positive Healthy Organizations: Promoting well-being, meaningfulness, and sustainability in organizations. Front. Psychol. 2017, 8, 1938. [CrossRef]

56. Algül, F. An Internet Radio from Turkey as an Example of Community Radio: Nor Radyo. AJIT-E $2013,4$. [CrossRef]

57. Morelli, J. Environmental Sustainability: A Definition for Environmental Professionals. J. Environ. Sustain. 2011, 1. [CrossRef]

58. Vinnari, M.; Vinnari, E. A Framework for Sustainability Transition: The Case of Plant-Based Diets. J. Agric. Environ. Ethics 2014, 27, 369-396. [CrossRef]

59. Okaka, W.; Nagasha, J.I. Climate Change Adaptation, Resilience, and Mitigation Communication Campaigns for Sustainable Development Goals (SDGs) in Africa. In Proceedings of the 22nd WFSF World Conference, Jondal, Norway, 7-10 June 2017.

60. Stern, P.C.; Dietz, T.; Guagnano, G.A. The new environmental paradigm in social psychological perspective. Environ. Behav. 1995, 27, 723-745. [CrossRef]

61. Ölander, F.; Thøgersen, J. Understanding consumer behavior as prerequisite for environmental protection. J. Consum. Policy 1995, 18, 345-385. [CrossRef]

62. Arora, V.; Ramakrishnan, N.; Fernandez, L. Community Radio E Sustainability: A Participatory Research Initiative; CEMCA: New Delhi, India, 2015.

63. Kahn, M. Concepts, definitions, and key issues in sustainable development: The outlook for the future. In Proceedings of the 1995 International Sustainable Development Research Conference, Manchester, UK, 27-28 March 1995; Keynote Paper; pp. 2-13.

64. Menou, M.J. Measuring the Impact of Information on Development; International Development Research Centre: Ottawa, ON, Canada, 1993.

65. McKenzie, S. Social Sustainability: Towards Some Definitions. Hawke Research Institute, University of South Australia, Magill, South Australia, Working Paper Series No 27. 2004. Available online: http:/ / naturalcapital. us/images/Social\%20Sustainability\%20 (accessed on 12 December 2018).

66. Buckley, S. Community Media: A Good Practice Handbook; United Nations Educational, Scientific and Cultural Organization: Paris, France, 2011.

67. Siemering, W. Radio, Democracy and Development: Evolving Models of Community Radio. J. Radio Stud. 2000, 7, 373-378. [CrossRef]

68. Kasoma, F. The Press and Multiparty Politics in Africa. PhD Thesis, University of Tampere, Tampere, Finland, 2000. Available online: http:/ / tampub.uta.fi/handle/10024/67090 (accessed on 26 December 2018).

69. Stenou, K. Universal Declaration on Cultural Diversity a Vision a Conceptual Platform, a Pool of Ideas for Implementation a New Paradigm. A Document for the World Summit on Sustainable Development, Johannesburg. 26 August-4 September 2002. Available online: https://unesdoc.unesco.org/ark:/48223/ pf0000127162 (accessed on 12 December 2018).

70. Axelsson, R.; Angelstam, P.; Degerman, E.; Teitelbaum, S.; Andersson, K.; Elbakidze, M.; Marcus, K.; Drotz, M.K. Social and Cultural Sustainability: Criteria, Indicators, Verifier Variables for Measurement and Maps for Visualization to Support Planning. AMBIO 2013, 42, 215-228. [CrossRef]

71. Librero, F. Community Broadcasting: Concept and Practice in the Philippines; Eastern Universities Press: Kuala Lumpur, Malaysia, 2004.

72. Uphoff, N.; Esman, M.J.; Krishna, A. Reasons for Success: Learning from Instructive Experiences in Rural Development; Kumarian Press: West Hartford, CT, UK, 1998.

73. Howley, K. Community Media: People, Places and Communication Technologies; Cambridge University Press: Cambridge, UK, 2005.

74. Fang, W.; Eric, N.; Wang, C.; Hsu, C. Normative Beliefs, Attitudes, and Social Norms: People Reduce Waste as an Index of Social Relationships When Spending Leisure Time. Sustainability 2017, 9, 1696. [CrossRef]

75. Bandura, A. Environmental sustainability by sociocognitive deceleration of population growth. In The Psychology of Sustainable Development; Schmuch, P., Schultz, W., Eds.; Kluwer Academic: Dordrecht, The Netherlands, 2002; pp. 209-238.

76. Kollmuss, A.; Agyeman, J. Mind the Gap: Why do people act environmentally and what are the barriers to pro-environmental behavior? Environ. Educ. Res. 2002, 8, 239-260. [CrossRef]

77. Di Fabio, A.; Peiró, J.M. Human Capital Sustainability Leadership to Promote Sustainable Development and Healthy Organizations: A New Scale. Sustainability 2018, 10, 2413. [CrossRef] 
78. Heath, J.S.; Fessenden-Raden, J. Communicating Risk: Factors Affecting Community Acceptance of Information. In New Risks: Issues and Management, Advances in Risk Analysis; Cox, L.A., Ricci, P.F., Eds.; Springer: Boston, MA, USA, 1990.

79. Pearce, J.; Russill, C. Interdisciplinary Environmental Education: Communicating and Applying Energy Efficiency for Sustainability. Appl. Environ. Educ. Commun. Int. J. 2005, 4, 65-72. [CrossRef]

80. Schenk, A.; Hunziker, M.; Kienast, F. Factors influencing the acceptance of nature conservation measures-A qualitative study in Switzerland. J. Environ. Manag. 2007, 83, 66-79. [CrossRef] [PubMed]

81. Happer, C.; Philo, G. The Role of the Media in the Construction of Public Belief and Social Change. J. Soc. Political Psychol. 2013, 1, 321-336. [CrossRef]

82. GFK. Radio ... Trusted and Authentic. Gfk Radio Insights 2017. GFK. 2017. Available online: http:/ / www.2cc. net.au/pdf/GFK_Trust_July_2017.pdf (accessed on 27 November 2017).

83. Tabing, L. How to Do Community Radio: A Premier for Community Radio Operators; UNESCO: New Delhi, India, 2002.

84. White, R. Ten major lines of research on grassroots, participatory communication in Africa. Afr. Media Rev. 2008, 1, 7-45.

85. Dagron, A.G. Making Waves: Stories of Participatory Communication for Social Change; The Rockefeller Foundation: New York, NY, USA, 2001.

86. Girard, B. (Ed.) The One to Watch: Radio New ICTs and Interactivity; FES Geneva and FAO: Rome, Italy, 2003.

87. Skuse, A. (Ed.) Radio Broadcasting for Health: A Decision Maker's Guide; Information and Communication for Development: London, UK, 2004.

88. Ngugi, P.K. Using Community Radios as a Tool for Development. J. Mass Commun. Journal. 2015, 5, 1-8.

89. Tucker, E. Community radio in political theory and development practice. J. Dev. Commun. Stud. 2013, 2, 392-420.

90. AMARC. 11th International Conference of the World Association of Community Radio Broadcasters (AMARC), Accra Ghana, 10-14 August 2015. Available online: http:/ /a11.amarc.org/ (accessed on 1 October 2017).

91. Weiss, J. Opening Community Radio with Low-Cost Tech. International Journalists' Network. 2014. Available online: tps:/ /ijnet.org/en/blog/opening-community-radio-low-cost-tech (accessed on 19 December 2017).

92. Anduvate, D.V. The Place of Community Radio in Rural Development in Kenya: Case Study of Sauti FM in Rarieda, Siaya County. Master's Thesis, The University of Nairobi, Nairobi, Kenya, 2014.

93. Gordon, J. How community Broadcasting is Funded-A Useful Resource for Community Broadcasters. Community Broadcasting Association of Australia, 2016. Available online: https://www.cbaa.org.au/ article/how-community-broadcasting-funded-\%E2\%80\%93-useful-resource-community-broadcasters (accessed on 18 December 2017).

94. Khan, M. Community Radio: Helping Save Lives during Cyclone Mora. The Daily Star, 2017. Available online: http:/ / www.thedailystar.net/star-weekend/community-radio-helping-save-lives-during-cyclonemora-1420594 (accessed on 27 October 2017).

95. Fombad, M.C.; Jiyane, G.V. The role of community radios in information dissemination to rural women in South Africa. Int. J. Librariansh. Inf. Sci. 2016, 1-12. [CrossRef]

96. Manda, L.Z. Importance of radio in agricultural value chains. In Addressing Information Gaps in Agricultural Value Chains: The Role of Radio Programming, Proceedings of the 3rd Annual Farm Radio Symposium, 23-24 November 2011; Manda, L.Z., Ed.; Farm Radio Malawi/Department of Agricultural Extension Services, Malawi Institute of Management: Lilongwe, Malawi, 2012; pp. 10-14.

97. Tacchi, J.; Watkins, J.; Keerthirathne, K. Participatory content creation: Voice, communication, and development. Dev. Pract. 2009, 19, 573-584. [CrossRef]

98. Buré, C. Stronger Voices? Experiences in Paraguay with Interactive ICTs. In ICTs for Global Development and Sustainability: Practice and Applications; Steyn, J., Belle, J.V., Mansilla, E.V., Eds.; IGI Global: Hershey, PA, USA, 2010; pp. 248-266.

99. Hughes, J. Transmutation of Digital Information Goods: Consumers Exercising the Power of Information Technology. In Proceedings of the 39th Hawaii International International Conference on Systems Science (HICSS-39 2006), CD-ROM/ Abstracts Proceedings, Kauai, HI, USA, 4-7 January 2006. Working Paper.

100. Agarwal, S.K.; Kumar, A.; Nanavati, A.A.; Rajput, N. Content Creation and Dissemination by-and-for Users in Rural Areas. In Proceedings of the 2009 International Conference on Information and Communication Technologies and Development (ICTD), Doha, Qatar, 17-19 April 2009; pp. 56-65. 
101. O'Neill, S.; Boykoff, M. The Role of New Media in Engaging the Public with Climate Change. In Engaging the Public with Climate Change; Whitmarsh, L., O'Neill, S., Lorenzoni, I., Eds.; Earthscan: London, UK, 2011.

102. Fröhlich, J.; Däschle, D.; Geerts, A.; Jannusch, S. Community Participation at Local and Community Radio Stations. An Explorative Study in Africa, Asia, Latin America and the Pacific. Available online: https:/ / www.cameco.org/media/general_report_final.pdf (accessed on 11 December 2018).

103. Murada, P.O.; Grover, A.M. Women's voices: Engaging the excluded. Rev. Mark. Integr. 2014, 6, 114-130. [CrossRef]

104. Al-Hassan, S.; Adani, A.; Malik-Abdul, A. The role of community radio in livelihood improvement: The case of Simli Radio. FACTS Rep. 2011, 5, 1-16.

105. Chapman, R.; Blench, R.; Kranjac-Berisavljevic, G.; Zakariah, A.B.T. Rural Radio in Agricultural Extension: The Example of Vernacular Radio Programmes on Soil and Water Conservation in N. Ghana; AgREN 127; CAB Direct: London, UK, 2003.

106. Alumuku, P.T. Community Radio for Development. The World and Africa; Pauline's Publications Africa: Nairobi, Kenya, 2006.

107. Govender, E.M.; Durden, E.; Reddy, S. How participatory is participatory communication for HIV / AIDS awareness in South Africa? Afr. Commun. Rev. 2010, 3, 281-303.

108. de Jong, K.; Albin, M.; Skärbäck, E.; Grahn, P.; Björk, J. Perceived green qualities were associated with neighborhood satisfaction, physical activity, and general health: Results from a cross-sectional study in suburban and rural Scania, southern Sweden. Health Place 2012, 18, 1374-1380. [CrossRef] [PubMed]

109. Gardner, R. Social Psychology and Second Language Learning; Arnold: London, UK, 1985.

110. Eagly, A.H.; Chaiken, S. The Psychology of Attitudes; Harcourt Brace Jovanovich: Fort Worth, TX, USA, 1993.

111. Nirmala, Y. The role of community radio in empowering women in India. Media Asia 2015, 42, 41-46. [CrossRef]

112. Mhagama, P. The importance of participation in development through community radio: A case study of Nkhotakota community radio station in Malawi. Crit. Arts 2016, 30, 46-51. [CrossRef]

113. Kuyucu, M. Community Radio Broadcasting: Use of Community Radio for Turkish and Greek in Turkey. In Proceedings of the 7th Annual International Conference on Mediterranean Studies, Athens, Greece, 14-17 April 2014; pp. 5-32.

114. Oroujlou, N.; Vahedi, D.M. Motivation, attitude, and language learning. International Conference on Education and Educational Psychology (ICEEPSY 2011). Procedia Soc. Behav. Sci. 2011, 29, 994-1000. [CrossRef]

115. Leiserowitz, A.A.; Kates, R.W.; Parris, T.M. Sustainability Values, Attitudes, and Behaviors: A Review of Multinational and Global Trends. Annu. Rev. Environ. Resour. 2006, 31, 413-444. [CrossRef]

116. Ajzen, I. Attitude structure and behavior. In Attitude Structure and Function; Pratkanis, A.R., Breckler, S.J., Greenwald, A.G., Eds.; Erlbaum: Hillsdale, NJ, USA, 1989; pp. 241-274.

117. Schutte, N.S.; Bhullar, N. Approaching Environmental Sustainability: Perceptions of Self-Efficacy and Changeability. J. Psychol. 2017, 151, 321-333. [CrossRef]

118. Bandura, A. Self-efficacy: Toward a unifying theory of behavioral change. Psychol. Rev. 1977, 84, $191-215$. [CrossRef]

119. Gosselin, J.T.; Maddux, J.E. Self-Efficacy. In Handbook of Self and Identity; Leary, M.R., Tangney, J.P., Eds.; The Guilford Press: New York, NY, USA, 2003; pp. 218-238.

120. Macinnis, D.J.; Jaworski, B.J. Information Processing from Advertisements: Toward an Integrative Framework. J. Mark. 1989, 53, 1-23. [CrossRef]

121. Bandura, A. Self-Efficacy: The Exercise of Control; Freeman: New York, NY, USA, 1997.

122. Bessette, G. Facilitating Dialogue, Learning and Participation in Natural Resource Management. In People, Land and Water Participatory Development Communication for Natural Resource Management; Bessette, G., Ed.; International Development Research Centre: Ottawa, ON, Canada, 2006; pp. 3-31.

123. Ben-Ami, M.; Hornik, J.; Eden, D.; Kaplan, O. Boosting consumers' self-efficacy by repositioning the self. Eur. J. Mark. 2014, 48, 1914-1938. [CrossRef]

124. Kallgren, C.; Raymond, R.; Cialdini, R. A Focus Theory of Normative Conduct: When Norms Do and Do not Affect Behavior. Personal. Soc. Psychol. Bull. 2000, 26, 1002-1012. [CrossRef] 
125. Salama, J. How New Media Is Influencing Our Social Norms. Sail Magazine. 2017. Available online: https:/ / sailemagazine.com/2017/09/how-new-media-is-sculpting-our-social-norms/\#.W5joDPa-nb0 (accessed on 28 October 2018).

126. Rivis, A.; Sheeran, P. Descriptive norms as an additional predictor in the theory of planned behaviour: A meta-analysis. Curr. Psychol. 2003, 22, 218-233. [CrossRef]

127. Tankard, M.E.; Paluck, E.L. Norm Perception as a Vehicle for social change. Soc. Issues Policy Rev. 2016, 10, 181-222. [CrossRef]

128. Poudel, S.; Nyaupane, G.P. Understanding environmentally responsible behaviour of ecotourists: The Reasoned Action Approach. Tour. Plan. Dev. 2017, 14, 337-352. [CrossRef]

129. Yanovitzky, I.; Stryker, J. Mass Media, Social Norms, and Health Promotion Efforts: A Longitudinal Study of Media Effects on Youth Binge Drinking. Commun. Res. 2001, 28, 208-239. [CrossRef]

130. Arias, E. How Does Media Influence Social Norms? Experimental Evidence on the Role of Common Knowledge. Political Sci. Res. Methods 2018, 1-18. [CrossRef]

131. Tufte, T.; Mefalopulos, P. Participatory Communication: A Practical Guide; The International Bank for Reconstruction and Development/The World Bank: Washington, DC, USA, 2009.

132. Bayton, J. Motivation, Cognition, Learning-Basic Factors in Consumer Behavior. J. Mark. 1958, 22, $282-289$.

133. Chwe, M. Rational Ritual: Culture, Coordination, and Common Knowledge; University Press: Princeton, NJ, USA, 2001.

134. Fishbein, M.; Ajzen, I. Predicting and Changing Behavior: The Reasoned Action Approach; Psychology Press: New York, NY, USA, 2010.

135. Ajzen, I. The Theory of Planned Behavior. Organ. Behav. Hum. Dec. 1991, 50, 179-211. [CrossRef]

136. Rosenstock, I.M. Historical origins of the health belief model. Health Educ. Quart. 1974, 2, 328-335. [CrossRef]

137. Strecher, V.J.; Champion, V.L.; Rosenstock, I.M. The health belief model and health behavior. In Handbook of Health Behavior Research: Personal and Social Determinants; Gochman, D.S., Ed.; Plenum Press: New York, NY, USA, 1997; pp. 71-91.

138. Stern, P.C.; Dietz, T.; Abel, T.; Guagnano, G.A.; Kalof, L. A value-belief-norm theory of support for social movements: The case of environmental concern. Hum. Ecol. Rev. 1999, 6, 81-97.

139. Ajzen, I. Perceived behavioral control, self-efficacy, locus of control, and the theory of planned behavior. J. Appl. Soc. Psychol. 2002, 32, 665-683. [CrossRef]

140. Bandura, A. Social cognitive theory and control over HIV infection. In Preventing AIDS: Theories and Methods of Behavioral Interventions; DiClemente, R.J., Peterson, J.L., Eds.; Plenum Press: New York, NY, USA, 1994; pp. 25-59.

141. Saunders, M.; Lewis, P.; Thornhill, A. Research Methods for Business Students, 5th ed.; Pearson Education Limited: Harlow, UK, 2009.

142. Bhatacherjee, A. Social Science Research: Principles, Methods, and Practices; Textbooks Collection. Book 3; University of South Florida: Tampa, FL, USA, 2012.

143. Ranjit, K. Research Methodology—A Step-By-Step Guide for Beginners, 2nd ed.; Pearson Education: Singapore, 2005.

144. O'Sullivan, E.; Rassel, G.R.; Berner, M. Research Methods for Public Administrators, 5th ed.; Pearson Education Inc.: New York, NY, USA, 2008.

145. Phellas, C.N.; Bloch, A.; Seale, C. Structured methods: Interviews, questionnaires and observation. In Researching Society and Culture; Seale, C., Ed.; SAGE Publications: London, UK, 2004; pp. 182-205.

146. Weller, S.C. Structured interviewing and questionnaire construction. In Handbook of Methods in Cultural Anthropology; Bernard, H.R., Ed.; AltaMira: Walnut Creek, CA, USA, 1998; pp. 365-409.

147. Alshenqeeti, H. Interviewing as a Data Collection Method: A Critical Review. Engl. Linguist. Res. 2014, 3 , 39-45. [CrossRef]

148. Gliem, J.; Gliem, R. Calculating, interpreting, and reporting Cronbach's Alpha Reliability Coefficient for Likert-type scales. Paper presented at the Midwest Research-to-Practice Conference in Adult, Continuing, and Community Education, The Ohio State University, Columbus, OH, USA, 8-10 October 2003.

149. Croasmun, J.T.; Ostrom, L. Using Likert-Type Scales in the Social Sciences. J. Adult Educ. 2011, 40, 19-22.

150. Jamieson, S. Likert scales: How to (ab) use them. Med. Educ. 2004, 38, 1217-1218. [CrossRef] [PubMed]

151. Byrne, B.M. Structural Equation Modeling with AMOS: Basic Concepts, Applications, and Programming, 3rd ed.; Routledge: Oxon, UK, 2016. 
152. Bollen, K.A. Total, direct, and indirect effects in structural equation models. Sociol. Methodol. 1987, 17, 37-69. [CrossRef]

153. Teo, T.; Tsai, L.T.; Yang, C. Applying Structural Equation Modeling (SEM) In Educational Research: An Introduction. In Application of Structural Equation Modeling in Educational Research and Practice; Khine, M.S., Ed.; Sense Publisher: AW Rotterdam, The Netherlands, 2013.

154. Hair, J.F.; Black, W.C.; Babin, B.J.; Anderson, R.E. Multivariate Data Analysis, 7th ed.; Prentice Hall: Englewood Cliffs, UK, 2010.

155. Gefen, D.; Straub, D.; Boudreau, M. Structural Equation Modeling and Regression: Guidelines for Research Practice. Commun. Assoc. Inf. Syst. 2000, 4, 1-70. [CrossRef]

156. Ringle, C.M.; Wende, S.; Becker, J.M. SmartPLS; SmartPLS GmbH: Boenningstedt, Germany, 2015.

157. Byrne, B. Structural Equation Modeling with AMOS: Basic Concepts, Applications, and Programming, 2nd ed.; Routledge: London, UK, 2010.

158. Hsu, M.K. Structural Equation Modeling with IBM SPSS Amos: A Methodology for Predicting Behavioral Intentions in the Services Sector; IBM Corporation: Somers, NY, USA, 2010.

159. Hair, J.F.; Sarstedt, M.; Hopkins, L.; Kuppelwieser, V.G. Partial least squares structural equation modeling (PLS-SEM). An emerging tool in business research. Eur. Bus. Rev. 2014, 26, 106-121. [CrossRef]

160. Kline, R. Principles and Practice of Structural Equation Modeling, 3rd ed.; the Guilford Press: London, UK, 2011.

161. Hair, J.F.; Ringle, C.M.; Sarstedt, M. Partial Least Squares Structural Equation Modeling: Rigorous Applications, Better. Results and Higher Acceptance. Long Range Plan. 2013, 46, 1-12. [CrossRef]

162. Hair, J.F.; Ringle, C.M.; Sarstedt, M. PLS-SEM: Indeed a silver bullet. J. Mark. Theory Pract. 2011, 19, $139-151$. [CrossRef]

163. Garson, G.D. Partial Least Squares: Regression E Structural Equation Models; G. David Garson and Statistical Associates Publishing: Asheboro, NC, USA, 2016.

164. Hair, J.F.; Sarstedt, M.; Ringle, C.M.; Mena, J.A. An assessment of the use of partial least squares structural equation modeling in marketing research. J. Acad. Mark. Sci. 2012, 40, 414-433. [CrossRef]

165. Raykov, T. Estimation of composite reliability for congeneric measures. Appl. Psychol. Meas. 1997, 21, $173-184$. [CrossRef]

166. Colwell, S.R. The composite reliability calculator. Tech. Rep. 2016. [CrossRef]

167. Fornell, C.; Larcker, D.F. Evaluating Structural Equation Models with Unobservable Variables and Measurement Error. J. Mark. Res. 1981, 18, 39-50. [CrossRef]

168. Field, A. Discovering Statistics Using SPSS, 3rd ed.; Sage: London, UK, 2009.

169. Henseler, J.; Ringle, C.M.; Sarstedt, M. A new criterion for assessing discriminant validity in variance-based structural equation modeling. J. Acad. Mark. Sci. 2015, 43, 115-135. [CrossRef]

170. Bagozzi, R.P.; Yi, Y. Specification, Evaluation, and Interpretation of Structural Equation Models. J. Acad. Mark. Sci. 2012, 40, 8-34. [CrossRef]

171. Hooper, D.; Coughlan, J.; Mullen, M.R. Structural Equation Modelling: Guidelines for Determining Model Fit. EJBRM 2008, 6, 53-60.

172. Hu, L.T.; Bentler, P.M. Cutoff Criteria for Fit Indexes in Covariance Structure Analysis. Conventional Criteria versus New Alternatives. Struct. Equ. Model. 1999, 6, 1-55. [CrossRef]

173. Field, A. Discovering Statistics Using IBM SPSS Statistics, 4th ed.; SAGE Publications Ltd.: London, UK, 2013.

174. Brown, T.A. Confirmatory Factor Analysis for Applied Research; Guilford Press: New York, NY, USA, 2015.

175. Bollen, K.A. Overall Fit in Covariance Structure Models: Two Types of Sample Size Effects. Psychol. Bull. 1990, 107, 256-259. [CrossRef]

176. Frost, J. Regression Analysis: How Do I Interpret R-Squared and Assess the Goodness-Of-Fit? Minitab. 30 May 2013. Available online: http:/ / www.minitab.com/ (accessed on 24 October 2017).

177. Steiger, J.H. Understanding the limitations of global fit assessment in structural equation modelling. Personal. Individ. Differ. 2007, 42, 893-898. [CrossRef]

178. Diamantopoulos, A.; Siguaw, J.A. Introducing LISREL; Sage Publications: London, UK, 2000.

179. Byrne, B.M. Structural Equation Modeling with LISREL, PRELIS and SIMPLIS: Basic Concepts, Applications and Programming; Lawrence Erlbaum Associates: Mahwah, NJ, USA, 1998. 
180. Larweh, K. And Our 'Perk' Was a Crocodile: Radio Ada and Participatory Natural Resource Management in Obane, Ghana. In People, Land and Water: Participatory Development Communication for Natural Resource Management; Bessette, G., Ed.; International Development Research Centre: Ottawa, ON, Canada, 2006; pp. 191-196.

181. Ouattara, S.; Ouattara, K. The Word that Quenches Their Thirst: Rural Media and Participatory Development Communication in Burkina Faso. In People, Land and Water Participatory Development Communication for Natural Resource Management; Bessette, G., Ed.; International Development Research Centre: Ottawa, ON, Canada, 2006; pp. 122-128.

182. Morgan, J. Participation, empowerment and capacity building: Exploring young people's perspectives on the services provided to them by a grassroots NGO in subSaharan Africa. Child. Youth Serv. Rev. 2016, 65, 175-182. [CrossRef]

183. BNNRC. Role of Community Media in Protecting Gender Based Violence. BNNRC, PLAN, Dhaka, Bangladesh [Originally Written in Bengali]. 2015. Available online: http:/ / bnnrc.net/bnnrc-publications / (accessed on 24 October 2017).

184. van Rooijen, L.; van Schelting, J. More and More Women Give Colour to Community Radio in Bangladesh. Free Press Unlimited, 2017. Available online: https:/ / www.freepressunlimited.org/en/blog/more-andmore-women-give-colour-to-community-radio-in-bangladesh (accessed on 28 October 2017).

185. Basselin, R.; Geertsma, R. Community Radio in Bangladesh. BBC Radio Bangladesh. 2017. Available online: https:/ / www.spotlightenglish.com/listen/community_radio_in_bangladesh (accessed on 28 October 2017).

186. WACC. Bangladesh Community Radio Celebrates Girl Power. Available online: http:/ /www.waccglobal. org/articles/bangladesh-community-radio-celeb (accessed on 28 October 2017).

187. UNESCO. Celebration of World Radio Day in Bangladesh. 2016. Available online: http://www.unesco. org/new / en/dhaka/about-us/singleview / news / celebration_of_world_radio_day_in_bangladesh / (accessed on 21 December 2017).

188. Alumuku, P.; White, R. A Paper on Community Radio in Ghana; UNESCO: Accra, Ghana, 2004.

189. Tavakol, M.; Dennick, R. Making sense of Cronbach's alpha. Int. J. Med Educ. 2011, 2, 53-55. [CrossRef] [PubMed]

190. Yu, C.Y. Evaluating Cutoff Criteria of Model Fit Indices for Latent Variable Models with Binary and Continuous Outcomes. Ph.D. Thesis, University of California, Los Angeles, CA, USA, 2002.

191. Bentler, P.M.; Bonnet, D.C. Significance Tests and Goodness of Fit in the Analysis of Covariance Structures. Psychol. Bull. 1980, 88, 588-606. [CrossRef]

192. McDonald, R.P.; Ho, M.H.R. Principles and Practice in Reporting Statistical Equation Analyses. Psychol. Methods 2002, 7, 64-82. [CrossRef] [PubMed]

193. Steckenreuter, A.; Wolf, I.D. How to use persuasive communication to encourage visitors to pay park user fees. Tour. Manag. 2013, 37, 58-70. [CrossRef]

194. Ullah, M.S. Community radio movement in Bangladesh: Will they work as citizens' media? Glob. Media J. 2010, 1, 1-11.

195. Ministry of Information, People's Republic of Bangladesh. Community Radio Installation, Broadcast and Operation Policy-2008. 201812 March. Available online: http://www.sancomonline.net/wp-content/ uploads/2015/02/c-r-policy-bangladesh-2008-2013_10_24-12_26_44-UTC.pdf (accessed on 12 December 2018).

196. Rasheed, A.A. Community Radio in Bangladesh: Achievement and Challenges-Recent Experience; BNNRC: Dhaka, Bangladesh, 2012.

197. GSMA Intelligence. ANALYSIS: Country Overview: Bangladesh. 2014. Available online: https://www. gsmaintelligence.com/research/?file=140820-bangladesh.pdf\&download (accessed on 24 October 2017).

198. ListOTop. Top 10 Countries by Number of Mobile Phones in Use. 2015. Available online: http:/ /www. listotop.com/top-10-countries-by-number-of-mobile-phones-in-use/ (accessed on 24 October 2017).

199. Internet World Stats. Top 20 Countries with Highest Number of Internet Users-June 30, 2017. 2017. Available online: http:/ / www.internetworldstats.com/top20.htm (accessed on 24 October 2017).

200. UNESCO. Community Radios Promote Local Development across Africa. UNESCO Office in Dakar-Media Services. 2014. Available online: http:/ / www.unesco.org/new/en/media-services/single-view/news/ community_radios_promote_local_development_across_africa/ (accessed on 24 October 2017).

201. Juutinen, C.A. Community and Its Radio. A Case Study of Chikuni Radio in Zambia. Master's Thesis, University of Tampere, Tampere, Finland, 2008. 
202. Ojomo, O.W.; Tejuoso, W.; Olayinka, A.P.; Oluwashola, I.T. Making a Case for Community Radio in Nigeria. Int. J. Hum. Soc. Sci. 2015, 5, 136-144.

203. PytlikZillig, L.M.; Hamm, J.A.; Shockley, E.; Herian, M.; Neal, T.M.S.; Kimbrough, C.; Tomkins, A.J.; Bornstein, B.H. The dimensionality of trust-relevant constructs in four institutional domains: Results from confirmatory factor analyses. J. Trust Res. 2016, 6, 111-150. [CrossRef]

204. PytlikZillig, L.M.; Kimbrough, C.D.; Shockley, E.; Neal, T.M.S.; Herian, M.N.; Hamm, J.A.; Bornstein, B.H.; Tomkins, A.J. A longitudinal and experimental study of the impact of knowledge on the bases of institutional trust. PLOS ONE 2017, 12, e0175387. [CrossRef]

205. CRSC/NEFEJ. Community MHz: Assessing Community Radio Performance in Nepal; A Pilot Assessment of 15 Stations; Community Radio Support Center (CRSC)/Nepal Forum of Environmental Journalists (NEFEJ with the Support of UNESCO): Kathmandu, Nepal, 2011.

206. OFCOM. Attitudes towards Local Radio: A Summary of the Findings of a Quantitative Survey of Local Radio Listeners. 2013. Available online: https://stakeholders.ofcom.org.uk/binaries/research/radio-research/ ressearch-findings13/attitudes.pdf?lang=en (accessed on 12 December 2018).

207. Smith, D. How Community Radio Is Helping Young Survivors Talk about Sexual Abuse. , 16 2015. The Guardian. 16 November 2015. Available online: https:/ /www.theguardian.com/social-care-network/2015/ nov/16/community-radio-young-people-child-sexual-exploitation-abuse (accessed on 17 December 2017).

208. Fisher, J.D.; Fisher, W.A. Changing AIDS risk behaviour. Psychol. Bull. 1992, 111, 455-474. [CrossRef]

209. Shumake-Guillemot, J.; Ebi, K.L.; Kabir, I.; Nguyen, T.; Malkawi, M. Scaling up community-based adaptation to protect health from climate change. In Community-Based Adaptation to Climate Change: Scaling It Up; Lisa, E.F., Schipper, J.A., Reid, H., Huq, S., Rahman, A., Eds.; Routledge: Oxon, UK, 2014; pp. 155-171.

210. Saroar, M.; Routray, J.K. Adaptation in situ or retreat? A multivariate approach to explore the factors that guide the peoples preference against the impacts of sea level rise in coastal Bangladesh. Local Environ. 2010, 15, 663-686. [CrossRef]

211. Jepson, A.; Clarke, A.; Ragsdell, G. Investigating the Application of the Motivation-Opportunity-Ability Model to Reveal Factors Which Facilitate or Inhibit Inclusive Engagement Within Local Community Festivals. Scand. J. Hosp. Tour. 2014, 14, 331-348. [CrossRef]

(C) 2019 by the authors. Licensee MDPI, Basel, Switzerland. This article is an open access article distributed under the terms and conditions of the Creative Commons Attribution (CC BY) license (http:/ / creativecommons.org/licenses/by/4.0/). 